\title{
Suriyeli Çocukların Eğitim ve Uyum Sorunlarının Değerlendirilmesi: Kızıltepe Örneği ${ }^{1}$
}

\author{
Abdurrahman ABAY ${ }^{2}$ \\ Fuat GÜLLÜPINAR ${ }^{3}$
}

\section{ÖZET}

Göç süreci yetişkinlere kıyasla çocukları çok daha fazla etkileyen bir süreçtir. Suriye'den göç eden mültecilerin yarısına yakını çocuk ve bu çocukların da büyük çoğunluğu okul çağındadır. Göç eden bu kitlenin içerisinde eğitim görmesi gereken önemli bir kitlenin olması sebebiyle karşımıza bu çocukların eğitim sorunu çıkmaktadır. Bu kapsamda bu çalışma da 2011 yılında Suriye'de yaşanan iç savaş sonrasında Türkiye'ye göç edip Mardin ilinin Kızıltepe ilçesine yerleşen eğitim çağındaki göçmen çocuklarının eğitim sürecindeki deneyimlerini ve eğitim sorunlarını analiz edip, sorun alanlarını tespit ederek yaşadıkları sorunlara çözüm önerileri sunmayı hedeflemiştir. Nitel yöntemle yapılan bu araştırma kapsamında, 20 Suriyeli Ortaöğretim öğrencisi, 6 veli, 5 öğretmen, 3 Suriyeli gönüllü eğitici (Koordinatör), 5 eğitim kurumu yöneticisi, 2 il-ilçe milli eğitim yöneticisi (Şube Müdürü) ve 4 (2 Sendika, 2 dernek) sivil toplum örgütü yöneticisi olmak üzere 45 kişi ile derinlemesine görüşme yapılmıştır. Saha çalışmasını gerçekleştirdiğimiz Kızıltepe'de eğitimine devam eden Suriyeli çocukların eğitim durumlarını incelediğimizde okulda yaşadıkları temel sıkıntının dil ve buna bağlı olarak iletişim sorunu olduğu görülmektedir. Katılımcıların neredeyse tamamı çocukların dil ve buna bağlı olarak iletişim sıkıntısı yaşadığını ifade etmiştir. Bu temel sorunun yanında Suriyeli çocuklar eğitimleri sürecinde, dersleri anlamada güçlük, buna bağlı olarak derslerde başarısızlık, dışlanma ve önyargılara maruz kalma, okul kültürüne uyum sağlayamama gibi pek çok konuda sıkıntı yaşamaktadırlar. Eğitim sürecinde yaşanan sorunların çözümüne yönelik olarak, Türkçe dil kurslarının artırılması, farklı programların uygulanması ve eğitimleri sürecinde mülteci çocuklara uzman desteğinin verilmesi gibi öneriler ön plana çıkmıştır. Ayrıca rehberlik çalışmalarını artırılması, sosyalleşme çalışmalarına ağırlık verilmesi ve okuldaki tüm personele hizmet içi eğitimin verilmesi diğer öneriler arasındadır.

Anahtar Kelimeler: Göç, entegrasyon, mülteci eğitimi, Suriyeli mülteciler, Kızıltepe

\section{Evaluation Of Syrian Children's Education and Integration Problem: Case Study in Kizıltepe}

\begin{abstract}
Migration process is a process that affects children more than adults. Almost half of the refugees who have migrated from Syria are children and the majority of these children are of school age. Since there is an important community in this immigrant community that should be educated, we encounter the educational problem of these children. In this scope the study is aimed at analysing the educational experience and problems faced by the immigrant children who immigrated to Turkey and settled in Kiziltepe district of Mardin province in 2011 following the Syrian civil war, and determining the problematic areas and proposing solutions to their

\footnotetext{
${ }^{1}$ Bu makale Anadolu Üniversitesi Sosyal Bilimler Enstitüsüne sunulmuş olan "Türkiye'de Suriyeli Çocukların Eğitim

Durumlarının Değerlendirilmesi: Kızıltepe Örneği” adlı yüksek lisans tezinden yararlanılarak üretilmiştir.

${ }^{2}$ Anadolu Üniversitesi Yüksek Lisans Öğrencisi, abdurrahmanabay@gmail.com

${ }^{3}$ Doç.Dr., Anadolu Üniversitesi, Sosyoloji Bölümü, fgullupinar@anadolu.edu.tr
} 
educational issues. Within the scope of this qualitative research, a total of 45 individuals consisting of 20 Syrian secondary school students, 6 parents, 5 teachers, 3 Syrian volunteer trainers (coordinators), 5 educational institution managers, 2 provincial-district national education managers (branch managers) and 4 nongovernmental organization managers ( 2 from the union, 2 from the association) were thoroughly interviewed. When we examine the educational status of the Syrian children who continue their education in Kizlltepe, where we conducted a field study, it is seen that the main problem they face in the school is the language and communication problems. Almost all of the participants stated that children had difficulty in language and communication. In addition to this basic problem, Syrian children have problems in their education, such as difficulty in understanding the lessons, failure in lessons, exclusion and prejudice, and inability to adapt to school culture. Suggestions such as increasing Turkish language courses, implementing different programs and providing expert support to refugee children during the education process have come to the fore in order to solve the problems experienced during the education process. In addition, increasing the guidance activities, focusing on socialization activities and providing in-service training to all staff in the school are among the other suggestions.

Keywords: Immigration, integration, refugee education, Syrian refugees, KızItepe

\section{GiRIŞ}

Göç basitçe insanların başka bir yere gitmesi değildir, kültürlerin, alışkanlıkların, anlayışların, yaşam tarzının, yeme içme örüntülerinin, çözüm yollarının ve tutumların vb. olguların da yer değiștirmesidir. Göç, esas olarak bireyin veya hanenin bir yerden bir yere taşınması veya taşınmak zorunda olması süreci olmakla birlikte bireyin o güne kadar bildiği ve sahip olduğu değerlerin, kültürün, alışkanlıkların kısacası bireyin yaşam sisteminin de başka bir yere yolculuğudur. Bireylerin göçüyle birlikte söz konusu olan, göç eden bireyin yaşam döngüsünde var olan her şeyin yer değiştirmesidir: Statünün, alışkanlıkların, kültürün, zenginlik ya da yoksulluğun, toplumsal cinsiyetin, ilişkiler setinin, yeme içme biçimlerinin, giyim tarzının ve deneyimlerin de yeni gidilen yere taşınması veya sürgünü...Y Yeni gelinen yerde bu ilişkiler setinin ve bireyin sahip olduğu maddi manevi her şey yeniden tanzim edilmek, düzenlenmek, elden geçirilmek, rehabilite edilmek, (doğal olarak) korunmak, değiştirilmek veya yeni duruma/koşullara uydurulmak zorundadır (Güllüpınar, 2019).

Şüphesiz, iletişim ve ulaşım teknolojilerinde yaşanan devrimler, 20. yüzyılı göçler çağı haline getirmiştir. Bu açıdan dünyadaki insanların önemli bir kısmının geçmişle kıyaslandığında, gittikçe daha fazla hareketlilik içinde olduklarını söyleyebiliriz. Ancak, bu teknolojik gelişmelerin yanı sıra dünyadaki zengin-yoksul ayrımının bölgeler arası eşitsizlikler düzeyinde dramatik boyutlarda devam ediyor olması, etnik ve siyasal çatışmalar, iç savaşlar, açlık ve kuraklık, ekolojik krizler, antidemokratik yönetimler ve güvenlik sorunları göçlerin gelecekte de artarak devam etmesinin sosyal, ekonomik ve kültürel arka planını oluşturmaktadır (Güllüpınar, 2019). Yalçın'a (2004, s.13) göre göç; toplumsal ve kültürel bir yer değişikliği durumudur. Bu durum ekonomik, politik, kişisel ya da çevresel sebeplerle bir bölgeden farklı bir bölgeye doğru gerçekleşir. Sürekli olarak bir yerde kalma amacıyla yapılabileceği gibi uzun, orta veya kısa süreli dönüş fikri ile de gerçekleşebilir.

Göç mekân üzerinde gerçekleşen hem çıkış hem de varış yerindeki ortamı etkileyip değiştiren insan hareketleri ile ilgili olduğu için temelde coğrafidir. Demografiktir çünkü hem kökendeki hem de varış yerindeki nüfus yapıları üzerinde etkili olur; nüfustaki değişimler (özellikle de işçilerin hareketi), alanlar arasındaki ekonomik dengesizliklerden kaynaklandığı ölçüde de ekonomiktir. Devletlerin, uluslararası göçmen ve mültecilerin çıkış ve girişlerini denetleme ve kısıtlama ihtiyacı hissettikleri yerlerde göç, politik bir sorun haline gelebilir. Ayrıca, göçmenlerin bulundukları yeri terk etme motivasyonlarının ve (göçü) kabul eden topluma uyum sorunlarının bulunması sebebiyle göç, sosyal psikolojik yönleri olan bir olgudur. Son olarak sosyal yapı ve kültürel sistemler, hem çıkış hem de varış yerlerinde göçmenlerin yaşamlarını etkilediği için sosyolojik bir olgudur (Boston, 2018, s. 42).

Göç, kişilerin bulundukları yerlerdeki şartların ihtiyaçlarına çözüm bulamadığı ya da daha iyi bir hayat için ihtiyaç duyulan koşulların kalmadığı hallerde ortaya çıkmaktadır. Bu şekilde bireyler ihtiyaçlarına cevap verebilecek ya da içinde bulundukları şartlardan kaçabilecekleri farklı bir mekânın peşine düşerler. Bu sürecin bir neticesi olarak karşımıza göç olgusu olarak çıkmaktadır (Beter, 2006, s. 5-6). Beter'in tanımlaması göçü, kurtuluşa ulaşmak için bir araç ve bir arayış süreci olarak göstermektedir. Fichter (2006, s. 180) ise göçü fiziki hareketlilik olarak karşımıza çıkarır. Fiziki hareketlilik çok sayıda kişinin isteği dışında bulunduğu mekândan başka bir mekâna yerleştirilmesi olarak tanımlanabilir. Bu 
mekân değişikliği, kabul görmeyen kişilerin aynı ülkede bir bölgeden diğerine sürülmesi şeklinde olabileceği gibi bir ülkeden diğerine doğru gerçekleştirilen mecburi göç şeklinde de olabilir.

Castles ve Miller (2008, s. 39), göçün birçok sebebinin olduğunu ve bu sebeplerden hiçbirinin tek başına insanların topraklarından ayrılıp başka ülkelere gitmeye karar verdiklerini tatmin edici bir şekilde açıklayamayacağını söyler. Göç etme nedenleri, insanları göç etmeye zorlayan sosyal, toplumsal, ekonomik, kültürel ve dini sebeplerden ayrı düşünülemez. Ayrıca iç göç ile dış göçü tetikleyen nedenlerin bir kısmı ortak iken bir kısmı farklılaşmaktadır.

Akan ve Arslan (2008, 21-25), iç göçlerin olmasının sebepleri arasında, hızlı bir şekilde artan nüfus, tarım alanında hızlanan teknoloji, sağlıktaki avantaj ve dezavantajlar, terörizm ve sebep olduğu huzursuzluk, yardımların bölgesel olarak eşit dağılmaması, çalışma olanaklarının azlığı; dış göçlerin sebeplerini ise: iktisadi sebepler, iş imkânlarındaki azalma, doğa koşulları sonucu gerçekleşen durumlar, iç çatışmalar, devletlerdeki yönetim sıkıntıları ve sözleşmelere bağlı olarak gerçekleşen ülkeler arasındaki nüfus değişimleri şeklinde sıralamıştır.

Savaş ve terör olayları göçün meydana gelmesinde etkili olan bir başka nedendir. Bu olaylar sonucunda taraf olmasalar bile sivillere yönelik gerçekleşen saldırı, katliam ve ağır kimyasal silahlar insanların topraklarını bırakmalarına sebebiyet vermiştir. I. Ve II. Dünya Savaşlarında milyonlarca insan göç etmek zorunda kalmıştır. Gene yakın dönemde yaşanan Suriye'deki iç savaş sebebiyle milyonlarca insan yerlerini terk etmek durumunda kalmıştır (Taşçı, 2009, s. 190). Geçen yarım yüzyılda bütün dünyayı etkileyen politik olayların akabinde, süreçte, mültecilik, sığınmacılık ve yerinden edilme gibi kavramların ortaya çıkması tesadüf değildir (Palabıyık ve Koç, 2011, s. 325-334).

2015'te dünya çapında uluslararası düzeyde göçmenlerin sayısının 244 milyon olduğu tahmin edilmekteydi ki bu dünya nüfusunun yaklaşık yüzde 3,5 gibi bir oranına tekabül etmektedir. Bu istatistik dünyanın önemli bir kısmının ülke sınırlarının içinde kaldığına işaret etmektedir ancak dünyada 744 milyon kadar insan da ülke içinde göç etmektedir. Bir taraftan da şunu tespit etmeliyiz, dünya nüfusu gittikçe geçmişte tahmin edilenden daha fazla göç etmektedir. Örneğin, 2003 yılında yapılan bir tahmine göre, 2050 yılında dünya nüfusunun yüzde 2,6 sının yani 230 milyon insanın göç edebileceği tahmini yapılmıştır. Ancak, şu anda bile bu tahminin çok ötesinde, daha fazla insan göç etmiş bulunmaktadır. 2010 yılında göçmen sayıları revize edilerek, 2010 yılında dünyada 405 milyon insanın göç edeceği tespiti yapılmıştır. Öte yandan, nüfus uzmanları dünyadaki göç eğilimlerinin hızının büyük bir oranda artışıyla birlikte, göçmen sayılarını tahmin etmenin güçlüğüne dikkat çekmektedirler (IOM, 2018, s. 2, 15). Bu belirsizliğin bir nedeni de şüphesiz ani gelişen ekonomik krizler ve jeopolitik olayların insanları büyük ölçüde göçe zorlayacağı ve yerlerinden edeceği olayların önceden kestirilemiyor oluşudur.

Göç sürecinin genişlemesinin önemli nedenlerinden biri, zincirleme göçün bir süre sonra kendi kendini besleyen bir sürece dönüşmesiyle ilişkilidir (Castles ve Miller, 2008, s. 299). Zincirleme göç, esasında sosyal ilişkilere, yakın akrabalık ve arkadaşlık bağlarına dayalı bir göç niteliğindedir. Sosyal ilişkiler, göçün devam etmesini sağlayan ve belli bir hızda devam etmesini kolaylaştıran güçlü bir göç nedenidir. Aile ve arkadaşlık ilişkileri üzerinden geliştirilen göçmen ağları, gittikleri ülkede belli bir cemaat oluşturmanın ve bu cemaatin gündelik hayatını idame ettirebilecekleri etnik temelde kurulan alışveriş merkezleri, bakkallar, ibadet yerleri, spor kulüpleri, dernekler, vakıflar, tercümanlar, doktorlar vb. yapılara temel oluşturur (Yılmaz ve Güllüpınar, 2019).

2010 yılında Tunus'ta seyyar satıcı bir gencin elinden alınan arabasına tepki olarak kendini yakması sonucu başlayan kitlesel eylemler birçok Ortadoğu ülkesini etkiledi. Arap Baharı olarak adlandırılan bu olaylar sonucunda siyasi olaylar, darbeler, iç çatışmalar ve savaşlar yaşanmış, bu yaşananların sonucunda da milyonlarca insan ülkesini terk etmek zorunda kalmıştır. Suriye ilk etapta bu olaylardan etkilenmemiş ise de 2011 yılından itibaren burada da olaylar yaşanmaya başlanmıştır. Tunus, Mısır, Libya, Suriye, Bahreyn, Ürdün ve Yemen gibi Arap ülkelerini etkileyen ve sonrasında gösteri ve silahlı çatışmalara kimi yerde yumuşak, kimi yerde sert rejim değişikliklerine sebep olurken, Suriye örneğinde ise yaklaşık 10 yıldır devam eden iç çatışmalara dönüşerek büyük bir insani kriz doğurmuştur. Yaşanan durumlardan dolayı Suriyeliler ülkelerini terk ederek komşu ülkelere sığınmaya başlamışlardır. Yurtlarını bırakarak komşu ülkelere sığınan Suriyeli sayısı yaklaşık 2 milyon iken; ülke içerisinde farklı bölgelere göç eden Suriyeli sayısı ise yaklaşık 5 milyonu bulmuştur. 2015 yılında geldiğimizde ise yer değiştiren Suriyeli sayısının 12 milyonu aştığı ve neredeyse Suriye nüfusunun yarısının mülteci konumuna düştüğü görülmektedir (UNHCR, 2015; AFAD, 2016). 
Suriye ile 911 km'lik bir sınıra sahip olan Türkiye 2011 yılında başlayan ve günümüze kadar süren Suriyeli akınından en çok etkilenen ülke olmuştur. Bu durumun farklı farklı sebepleri olmakla birlikte Türkiye'nin jeopolitik konumu, yakınlığı, Avrupa'ya açılan kapı olarak görülmesi ve Suriye'deki çatışmaların başlamasından kısa bir süre sonra izlediği "Açık Kapı Politikası” bu durumun oluşmasının temel sebepleri olarak sayılabilir. Suriye'den Türkiye'ye ilk toplu nüfus hareketi, 29 Nisan 2011 tarihinde Hatay ili Yayladağ ilçesindeki Cilvegözü sınır kapısından 252 kişilik bir grupla olmuş, ardından bu girişler günümüze kadar neredeyse kesintisiz sürmüştür. Göç İdaresi Genel Müdürlüğünün kayıtlarına göre, Ekim 2019 itibari ile Türkiye'de kaydedilen Suriyeli sığınmacı sayısı üç buçuk milyonu geçmiştir (GİGM, 2019).

Krizin başladığı dönemlerde bu durumun çok uzun sürmeyeceği ve Türkiye'ye sığınan Suriyelilerin kısa bir zaman diliminde evlerine döneceği varsayılmaktaydı. Bu nedenle Türkiye'deki Suriyeli sığınmacılara önce "misafï" olarak bakıldı ve buna bağlı olarak çözüm önerileri de kısa vadeli olarak planlandı. $\mathrm{Bu}$ temelde temel ihtiyaçları karşılanarak belli bölgelerde toplanmaları gerektiği düşüncesiyle Suriye'ye yakın il ve ilçelerde geçici barınma merkezleri oluşturuldu. Ancak Suriye'deki savaş ve çatışmalar beklendiği gibi kısa sürmemiş, hatta şiddetlenerek devam etmiş ve Türkiye'deki Suriyelilerin uzun yıllar kalacakları fikri oluşmaya başlamıştır. Geçici barınma merkezleri artırılsa da Suriyelilere yetmemiş ve Suriyeliler Türkiye'nin her tarafına dağılmaya başlamıştır. Sayıları her geçen gün artan Suriyeli sığınmacıların, süreç içerisinde ülkede kalma eğiliminin sürekli arttı̆g ve Suriye'deki iç savaş sona erse bile önemli bir kısmının ülkelerine dönmeyeceği tahmin edilmektedir (Kutlu, 2015; Sirkeci, 2017, s. 21-40; Orhan ve Şenyücel, 2015). Bu durum hem Türkiye toplumu açısından hem de Suriyeliler açısından sosyal uyum politikalarının hızla planlanması ve uygulanması gerekliliğini doğurmuştur.

Barınma merkezlerinde kalan sığınmacıların barınma ve beslenme gibi temel ihtiyaçlarının tamamı karşılanmakta, ayrıca bu merkezlerin içinde veya dışında oluşturulan Geçici Eğitim Merkezlerinde Suriyeli çocukların eğitim ihtiyaçları da karşılanmaya çalışılmıştır. Ancak Göç İdaresi Genel Müdürlüğü'nün (GIGM) (2019) verilerine baktı̆̆ımızda Türkiye'ye sığınmış olan mültecilerin \%2'yi bulmayan çok az bir kesiminin bu kamplarda kaldığı görülmektedir. Geriye kalan \%98'den fazla bir kesim ise Türkiye'nin hemen hemen tüm şehirlerine dağılmış ve farklı farklı koşullarda yaşamlarını sürdürmektedir. Savaş ortamından kaçıp Türkiye'nin dört bir tarafında yaşayan Suriyeliler, sosyal, ekonomik ve psikolojik gibi pek çok problem yaşamakta ve bu konularda desteğe ihtiyaç duymaktadirlar.

Göç süreci yetişkinlere kıyasla çocukları çok daha fazla etkilemektedir. Suriye'den göç eden mültecilerin yarısına yakını çocuk ve bu çocukların da büyük çoğunluğu okul çağındadır. Eğitim görmesi gereken önemli bir kitlenin olması sebebiyle karşımıza bu çocukların eğitim sorunu çıkmaktadır. Suriyeli çocukların eğitimlerine yönelik izlenen politikalar, ilk etapta Suriyelilerin geri dönecekleri varsayımı üzerinden geliştirilmeye çalışılmış ve kısa vadeli bu politikalar sadece kamp içindeki Suriyeli çocuklara yönelik hazırlanmıştır. Daha açık ifade ile 2012 yılında MEB tarafından Suriyelilere Türkçe öğretmek yerine Arapça müfredat ile eğitimleri desteklenmiştir. $\mathrm{Bu}$ vesile ile Suriyelilerin geri döndüklerinde herhangi bir sorun yaşamaması hedeflenmiştir (Dinçer, 2012).

2013 yılına gelindiğinde, Suriye'deki iç savaş ve şiddet azalmamış beklentinin aksine daha da şiddetlenerek sürmüştür. Ülkelerinden kaçan Suriyelilerin Türkiye'ye sığınmaları neticesinde Türkiye'deki Suriyelilerin sayısı ise günden güne artmıştır. Türkiye'ye gelen Suriyelilerin en azından yakın bir gelecekte ülkelerine geri dönmeyeceklerinin anlaşılması üzerine ilk başta gündeme gelmeyen eğitim sorunu günden güne daha çok konuşulmaya başlanmıştır. Dahası, Suriyeli ailelerin 3 yıldan beridir eğitimsiz kalan çocukları için gelecekte engellenemez problemlerin ortaya çıkma riski de düşünülmeye başlanmıştır (Seydi, 2014, s. 268-269). Bunun üzerine eğitim gibi ihmal edilmemesi gereken bir alana yönelik düzenlemeler çıkarılan yönetmelik ve genelgelerle ancak 2014 yılının sonlarına doğru sistematik bir çerçevede ele alınmaya başlanmıştır.

Suriyeli sığınmacılara yönelik eğitim hizmetlerinin elbette ki çok büyük önemi ve faydası vardır. Ancak Türkiye'de bulunan Suriye nüfusunun 3,6 milyonu geçtiği ve okul çağındaki Suriyeli çocukların 1 milyonun üzerinde olduğu gerçeği bu çalışmaların yeterli olmayacağını bize net bir şekilde göstermektedir. Hala yüzbinlerce Suriyeli çocuk eğitim ve öğretime erişebilmiş değildir. Bu erişimin birden olması elbette düşünülemez ancak hızlanması için bazı çalışmaların yapılması gerektiği aşikârdır. En temelde var olan sorunlar tespit edilirse bir yol alınmış olacaktır. Suriyeli sığınmacıların 
eğitim sürecinde yaşadıkları sorunları ve deneyimleri belirlemek hem eğitime erişimde hem de daha nitelikli ve verimli bir eğitim almada önem teşkil etmektedir.

\section{YÖNTEM}

Araştırmanın konusunu, Suriye'den Türkiye'ye göç etmiş ve ortaöğretim düzeyinde öğrenim gören çocuklar oluşturmaktadır. Araştırma, ortaöğretimde eğitim gören Suriyeli sı̆̆ınmacı çocukların içinde bulundukları toplumsal koşulları, bu koşulları deneyimleme ve anlamlandırma biçimlerini ve bu kapsamda eğitimde karşılaştıkları sorunlara odaklanmaktadır. Ayrıca çalışma kapsamında, eğitim gören bu çocukların ebeveynlerinin ve öğretmenlerinin süreci nasıl değerlendirdikleri de açıklanmaya çalışılmıştır.

$\mathrm{Bu}$ çerçevede çalışmanın temel amacı ise Suriyeli sığınmacıların eğitim süreci içerisindeki deneyimleri, mücadele alanlarını ve karşılaştıkları temel sorunları tespit etmek ve bu sorunları nasıl okudukları üzerine 1şık tutmaktır. Suriyeli sığınmacıların sosyal ve ekonomik alanlara dahil olma / ol(a)mama durumları, geliştirdikleri yaşam stratejileri ve dayanışma ağları ile eğitimde yaşadıkları sıkıntıların yanında eğitime yükledikleri anlam ve eğitim koşulları hakkında bir çerçeve çizilmeye çalışılacaktır.

Araştırmada öncelikle konu ile ilgili literatür taranmış ve verileri katılımcılardan en uygun şekilde toplamak maksadıyla yarı yapılandırılmış görüşme formları geliştirilmiştir. Formların geliştirilmesinden sonra gerekli yasal izinler alınıp Kızıltepe'de yaşayan eğitim çağındaki çocuklarla, Suriyeli ailelerle, Suriyeli çocukların derslerine giren öğretmenlerle, Suriyeli koordinatörler ve okul müdürleriyle ayrıca il milli eğitim yöneticileri, vakıf ve sivil toplum örgütleriyle yarı yapılandırılmış görüşmeler yapılmıştır.

Görüşmeler ile katılımcılardan Suriyeli öğrencilerin eğitimleri sırasında yaşadıkları problemler ve bu problemlerin çözümüne dair talep, beklenti ve önerilerinin ne olduğu bunun yanında araştırmaya katılan diğer katılımcıların da konu hakkındaki görüş ve düşüncelerinin neler olduğuna dair derinlemesine veri toplanmaya çalışılmıştır. Suriyeli çocuklar ve velileri ile Türkçe ve Kürtçe dillerinde veriler toplanmış olup bu durum katılımcının kendisini hangi dilde daha rahat ifade edebileceğine bağlı olarak katılımcının tercihine bırakılmıştır. Görüşmeler 20-30 dakika devam etmiş. Yarı yapılandırılmış sorular katılımcılara yöneltilerek verdikleri yanıtlar katılımcıların isimleri kodlanarak görüşme formuna kaydedilmiştir.

Araştırmanın çalışma grubunu, Suriye'den Türkiye'ye göç etmiş ve halen Mardin ilinin Kızıltepe İlçesi'nde yaşamlarını sürdüren eğitim çağındaki 20(3'ü mezun) öğrenci, 6 Suriyeli veli, Kızıltepe'de Suriyeli öğrencilerin öğrenimlerine devam ettiği okullardaki 5 öğretmen, 3 okul müdürü, 2 Müdür yardımcısı, 3 Suriyeli gönüllü eğitici (Koordinatör), 2 il milli eğitim yöneticisi (2 il milli eğitim şube müdürü) ve Kızıltepe'de aktif bir şekilde hizmet veren 4 sivil toplum örgütü(2 sendika, 2 yardım derneği) yöneticisi olmak üzere toplam 45 kişi oluşturmaktadır.

\subsection{Katılımcıların Kişisel Bilgileri}

$\mathrm{Bu}$ başlıkta çalışmaya katılan kişilerin bilgilerine yer verilecek olup ayrıca katılımcıların görüşleri isim verilmeden aktarılacağı için her katılımcıya bir kod ve kodun yanında bir numara verilmiştir. Örneğin; Suriyeli çocuklar için Ç1, Ç2..., Suriyeli veliler için V1, V2..., öğretmenler için Ö1, Ö2..., yöneticiler

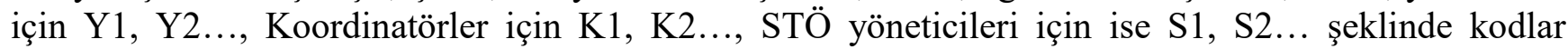
kullanılmıştır.

Tablo 1. Araştırmaya Katılan Suriyeli Öğrenciler

\begin{tabular}{cccccc}
\hline Katılımcı & Cinsiyeti & Yaşı & $\begin{array}{c}\text { Kizıltepe'de } \\
\text { ikamet } \\
\text { süresi(yıl) }\end{array}$ & Okul durumu & Göç ettiği yer \\
\hline Ç1 & Kadın & 17 & 4 & Devam Ediyor & Halep \\
Ç2 & Kadın & 14 & 6 & Devam Ediyor & Şam \\
Ç3 & Erkek & 17 & 4 & Devam Ediyor & Şam \\
Ç4 & Kadın & 23 & 7 & Mezun & Şam
\end{tabular}




\begin{tabular}{cccccc} 
Ç5 & Erkek & 19 & 4 & Devam Ediyor & Halep \\
Ç6 & Kadın & 16 & 5 & Devam Ediyor & Hasekê \\
Ç7 & Kadın & 19 & 4 & Devam Ediyor & Kobanê \\
Ç8 & Erkek & 23 & 8 & Mezun & Halep \\
Ç9 & Erkek & 19 & 6 & Devam Ediyor & Rakka \\
Ç10 & Erkek & 14 & 5 & Devam Ediyor & Şam \\
Ç11 & Kadın & 17 & 4 & Devam Ediyor & Kobanê \\
Ç12 & Erkek & 24 & 6 & Mezun & Dirbêsîyê \\
Ç13 & Erkek & 15 & 8 & Devam Ediyor & Dirbêsîyê \\
Ç14 & Erkek & 15 & 4 & Devam Ediyor & Şam \\
Ç15 & Erkek & 15 & 5 & Devam Ediyor & Hasekê \\
Ç16 & Erkek & 17 & 8 & Devam Ediyor & Qamişlo \\
Ç17 & Erkek & 17 & 8 & Devam Ediyor & Şam \\
Ç18 & Erkek & 16 & 6 & Devam Ediyor & Amûdê \\
Ç19 & Kadın & 18 & 6 & Devam Ediyor & Qamişlo \\
Ç20 & Kadın & 17 & 5 & Devam Ediyor & Qamişlo \\
\hline
\end{tabular}

Araştırma kapsamında Kızıltepe'de yaşayan okul çağındaki 20 Suriyeli Öğrenci ile görüşmeler yapılmıştır. Tabloyu incelediğimizde bu öğrencilerin 3'ü liseden mezun olmuş, diğerleri ise K1zıltepe'de devlet liselerinde eğitimlerine devam etmektedirler. Araştırma kapsamında görüşülen öğrencilerin 12'si erkek, 8'i kadın olmak üzere, 3'ü Halep, 6's1 Şam, 2'si Hasekê, 2'si Kobanê, 2'si Dirbêsîyê, 3'ü Qamişlo, 1'i Rakka ve 1'i de Amûdê illerinden gelmiş bireylerdir. Yaşları 14 ile 24 arasında değişen bu öğrencilerden tamamı 4 yıl ve üzeri süredir yaşamlarını Kızıltepe'de geçirmektedirler.

Tablo 2. Araştırmaya Katılan Suriyeli Veliler

\begin{tabular}{ccccc}
\hline Katılımcı & Cinsiyeti & Yaşı & $\begin{array}{c}\text { Kızıltepe'de ikamet } \\
\text { süresi(yıl) }\end{array}$ & Göç ettiği yer \\
\hline V1 & Kadın & 47 & 6 & Hasekê \\
V2 & Kadın & 45 & 6 & Hasekê \\
V3 & Kadın & 34 & 6 & Serê Kaniyê \\
V4 & Erkek & 45 & 4 & Halep \\
V5 & Erkek & 50 & 7 & Hasekê \\
V6 & Erkek & 44 & 5 & Qamişlo \\
\hline
\end{tabular}

Tablo 2' de görüldüğü üzere, Kızıltepe'de hayatlarını sürdüren Suriyeli 6 Veli ile araştırma kapsamında görüşmeler gerçekleștirilmiștir. Görüşme yapılan velilerden 3'ü erkek 3'ü kadındır. Bunlardan 3'ü Hasekê biri Halep, biri Qamişlo ve biri de Serê Kaniyê şehirlerinden göç etmiş kişilerdir. Yaşları 34 ile 50 arasında bulunan bu veliler 4 yıldan fazladır Kızıltepe'de yaşamaktadırlar.

Tablo 3. Araştırmaya Katılan Öğretmen ve Yöneticiler

\begin{tabular}{ccccc}
\hline Katılımcı & Cinsiyeti & Görevi & $\begin{array}{c}\text { Mesleki } \\
\text { deneyim(yıl) }\end{array}$ & $\begin{array}{c}\text { Görev yaptı̆̆ } \\
\text { okul kademesi }\end{array}$ \\
\hline Ö1 & Erkek & Öğretmen & 8 & Lise \\
Ö2 & Kadın & Öğretmen & 4 & Lise \\
$\ddot{\text { Ö3 }}$ & Erkek & Öğretmen & 5 & Lise \\
$\ddot{\text { Ö4 }}$ & Kadın & Öğretmen & 6 & Lise \\
Ö5 & Kadın & Öğretmen & 2 & Ortaokul \\
K1 & Erkek & Koordinatör & 5 & Ortaokul \\
K2 & Erkek & Koordinatör & 3 & Ortaokul \\
K3 & Kadın & Koordinatör & 4 & Ortaokul
\end{tabular}




\begin{tabular}{llccc} 
Y1 & Erkek & Okul Müdürü & 17 & Ortaokul \\
Y2 & Erkek & Okul Müdürü & 15 & Lise \\
Y3 & Erkek & Okul Müdürü & 13 & Lise \\
Y4 & Erkek & Okul Müdür Yardımcıs1 & 7 & Ortaokul \\
Y5 & Erkek & Okul Müdür Yardımcıs1 & 20 & Lise \\
Y6 & Erkek & MEM İl Şube Müdürü & 17 & İl MEM \\
Y7 & Kadın & MEM İl Şube Müdürü & 15 & İ MEM \\
\hline
\end{tabular}

Araştırma kapsamında, Kızıltepe'de devlet okullarında eğitimine devam eden öğrencilere ders veren 5 öğretmen, Suriyeli öğrencilerin eğitim gördükleri okullarda onların eğitim durumu ile ilgilenen 3 Suriyeli Koordinatör, bu okullarda çalışan 5 tane okul yöneticisi ve 2 Milli Eğitim İl şube müdürü ile görüşmeler yapılmıştır.

Tablo 4. Araştırmaya Katılan STÖ ve Yöneticilerine İlişkin Bulgular

\begin{tabular}{cccc}
\hline Katılımc & Cinsiyeti & Görevi & Kurum \\
\hline S1 & Kadın & Proje Koordinatörü & Koruma ve Güçlendirme Derneği \\
S2 & Kadın & Proje Koordinatörü & Yardım ve Güçlendirme Derneği \\
S3 & Erkek & Sendika Şube Başkanı & Sendika \\
S4 & Erkek & Sendika Şube Yöneticisi & Sendika \\
\hline
\end{tabular}

Çalışma kapsamında Kızıltepe'de faaliyet yürüten eğitim alanında çalışan 2 sendika ve yardım, koruma ve güçlendirme alanlarında faaliyet gösteren 2 dernek ile görüşme yapılmıştır.

$\mathrm{Bu}$ araştırma nitel yöntemle yapılmış olan bir vaka (durum) çalışması olup araştırma verilerinin çözümlenmesinde, içerik analizi yöntemi kullanılmıştır. İçerik analiz yöntemiyle verileri tanımlama ve verilerin içinde saklı gerçekleri ortaya çıkarmak amaçlanmaktadır. Verilerin analizinde her katılımcının bir soruyla ilgili birden fazla görüşü olduğundan katılımcı frekansı yerine görüş frekansı verilmiştir. Dolayısıyla da toplam frekansa yer verilmemiştir. Araştırmanın ana ve alt temaları aşağıda verilmiştir.

Tablo 5. Araştırmanın Ana ve Alt Temaları

1. Kızıltepe'ye Yerleşen Suriyelilerin Genel Durumuna İlişkin Bulgular

1.1. Suriyelilerin Türkiye'yi Seçme Nedenleri

1.2. Suriyelilerin Kızıltepe'ye Yerleşme Nedenleri

1.3. Kızıltepe'de Yaşayan Suriyelilerin Geleceğe Yönelik Planları

1.4. Kızıltepe'deki Suriyelilerin Yaşadıkları Genel Sorunlar

1.5. Suriyelilerin Yaşadıkları Sorunların Giderilmesine Yönelik Çalışmalar

2. Kızıltepe'de Eğitimine Devam Eden Suriyeli Öğrencilere İlişkin Bulgular

2.1. Suriyeli Öğrencilerin Okulda Yaşadıkları Sorunlar

2.2. Okulda Yaşanan Sorunların Çözümüne Yönelik Alınan Tedbirler

2.3. Suriyelilerin Eğitimleri Noktasındaki Talep ve Beklentileri

2.4. Eğitimde Yaşanan Sorunların Çözümüne Yönelik Öneriler

2.5.Okulun Suriyeli Öğrencilere Katkıları

Yukarıdaki tabloda da görüldüğü üzere araştırma, iki ana ve on alt temadan oluşmaktadır. Elde edilen bulgular bu iki ana tema ve on alt tema başlığı altında sırayla irdelenecektir.

\section{BULGULAR VE YORUM}

$\mathrm{Bu}$ bölümde araştırmada elde edilen veriler ana ve alt tema başlıkları altında verilmiştir. İlk ana tema başlığı altında Kızıltepe'ye yerleşen Suriyelilerin genel durumuna ilişkin bulgular irdelenecektir. Bu kapsamda Suriyelilerin Türkiye'ye gelme ve Türkiye'yi seçme sebepleri, Türkiye'ye göç eden Suriyeli mültecilerin Kızıltepe'ye yerleşme nedenleri, geleceğe yönelik planları, yaşadıkları genel sorunlar ve bu sorunların giderilmesine yönelik yapılan çalışmalar ortaya konacaktır. İkinci ana temada ise bu 
araştırmanın asıl konusu olan eğitim çağındaki Suriyeli çocukların Eğitimde yaşadıkları sıkıntılar, yaşanan sorunların çözümüne yönelik alınan tedbirler, Suriyelilerin eğitimlerine yönelik talep ve beklentileri, eğitimde yaşanan sorunların çözümüne yönelik öneriler ve okulun Suriyeli öğrencilere katkıları irdelenecektir.

\subsection{Kızıltepe’ye Yerleşen Suriyelilerin Genel Durumuna İlişkin Bulgular}

Bu tema altında Suriyelilerin göç etmede Türkiye'yi seçme sebepleri, Kızıltepe'ye yerleşme sebepleri ve ilerideki planlarının yanı sıra, Kızıltepe'de yaşayan Suriyelilerin genel olarak karşılaştıkları problemlere ve bu problemlerin çözümü konusunda yapılan çalışmalara yönelik elde edilen veriler alt başlıklar halinde verilmiştir.

\subsubsection{Suriyelilerin Türkiye'ye gelme ve Türkiye'yi seçme sebepleri}

Suriyeli veliler ve çocuklarının göç sürecinde Türkiye'ye gelme ve Türkiye'yi seçme sebeplerine ilişkin görüşleri aşağıdaki tabloda verilmiştir.

Tablo 6. Suriyelilerin Türkiye'ye Gelme ve Türkiye'yi Tercih Etme Sebepleri

\begin{tabular}{lccc}
\hline Görüșler & Çocuk & Veli & Frekans \\
\hline Türkiye'nin güvenli bir yer olması & 9 & 5 & 14 \\
Türkiye'nin yakın olması & 7 & 4 & 11 \\
Yerleşen akrabalarının olması & 6 & 3 & 9 \\
Daha iyi bir gelecek için & 4 & 3 & 7 \\
Türkiye'de akrabalarının olması & 4 & 1 & 5 \\
Suriye'nin yaşanabilir bir yer olmaktan çıkması & 5 & 0 & 5 \\
Ailedeki ölümlerin artması & 3 & 0 & 3 \\
Eğitimime devam etmek için & 1 & 1 & 2 \\
Bulunulan yerde çoğunluğun Türkiye'ye gelmesi & 1 & 1 & 2 \\
Aslen buralı olmamız & 2 & 0 & 2 \\
\hline
\end{tabular}

Tablo 6'yı incelediğimizde Suriye'de yaşanan savaş nedeniyle göç etmek durumunda kalan Suriyelilerin Türkiye'ye gelme ve Türkiye'yi tercih etme sebeplerinin farklılaştığını söyleyebiliriz. Tablodaki verilere göre katılımcıların yarısından fazlası (9 çocuk, 5 Veli) göç sürecinde Türkiye'yi seçme sebeplerinin Türkiye'nin güvenli bir yer olduğunu düşünmeleridir. Velilerden 1'i bu durumu; "Ya Irak zaten yakın zamanında yıkılmıştı. Lübnan da küçük bir devletti ve küçük küçük bir sürü grubun mücadelesi olan bir yer. Önümüzde tek seçenek Türkiye kallyordu. Bir de Türkiye'den iyi bahsediyorlardı. Siğınılabilecek, çalışma koşullarının olduğu bir yer diye bahsediliyordu hep. Benden öncekiler hep bunu diyorlardı (V5). ” şeklinde dile getirmiştir. Gene tablodaki bilgiler 1şı̆̆ında çocuk ve velilerden 11'i Türkiye'nin coğrafi olarak Suriye'ye yakın olması ve sınır komşusu olmasını Türkiye'ye göç etmelerine yol açan önemli etkenlerden biri olarak ifade etmiştir. Bunun yanında Türkiye'nin göç etmede seçilmesinin etkin nedenlerinden birinin akrabalık ilişkileri olduğu görülmektedir. Türkiye'yi seçme nedeni olarak akrabalık bağlarını gösteren toplamda 14 katılımcı (bunların 9'u akrabaları daha önce Türkiye'ye gelenler ve 5'i de Türkiyeli akrabaları olanlar) bulunmaktadır. Yukarıdaki sebepler dişında daha iyi bir gelecek kurmak için, Suriye'nin yaşanabilir bir yer olmaktan çıkması, savaş sonucu ölümlerin artması veya göç edilen yerdeki çoğu kişinin Türkiye'yi seçmesi tercihlerinde etkili olan durumlar arasındadır.

\subsubsection{Suriyelilerin Kızltepe'ye yerleşme sebepleri}

Kızıltepe’ye yerleşen Suriyelilerin sosyal ağlar üzerinden burada kaldığını söylemek mümkün. Katılımcıların neredeyse tamamının ya yerli akrabası ya daha önce buraya göç etmiş akrabası ya da bir arkadaşı olduğu görülmektedir. Bu durum Kızıltepe'ye yerleşen Suriyelilerin sosyal ağlarının çok güçlü olduğunu ve buraya yerleşmelerinde bu ağların çok büyük etkisinin olduğunu göstermektedir. Suriyeli velilerin ve çocukların Kızıltepe'ye yerleşme sebepleri aşağıdaki tabloda sıralanmıştır. 
Tablo 7. Suriyelilerin Kızıltepe'ye Yerleşme Sebepleri

\begin{tabular}{lccc}
\hline Görüşler & Çocuk & Veli & Frekans \\
\hline Yerli halk ile iletişim kurabiliyor olmamız & 11 & 6 & 17 \\
Yerli akrabalarının olması & 12 & 1 & 13 \\
Kızıltepe'ye önceden yerleşen akrabalarının olması & 6 & 2 & 8 \\
Ailedekilerin çalışacak bir iş bulması & 5 & 2 & 7 \\
Kızıltepe'nin Suriye'ye sınır komşusu olması & 4 & 3 & 7 \\
Kalacak bir evin bulunması & 2 & 0 & 2 \\
Arkadaşlık & 1 & 0 & 1 \\
Özel bir nedeni yok & 1 & 0 & 1 \\
\hline
\end{tabular}

Tablo 7'deki verilere göre Kızıltepe'de ikamet eden çocukların yarısından fazlası ve velilerin tamamı Kızıltepe'ye yerleşme sebeplerinin temelini iletişim kurabilmeye bağlamıştır. Çocuklardan biri bu durumu; "Çok dolaştık en uygunu burası oldu. İlk geldiğimde Adana'ya gittim 7 ay kaldım orada. Sonrasinda İstanbul, Mersin ve Izmir'e gittim. Hepsi sikıntıllydı. Malum biraz dil anlama durumundan dolayı. Dil bilmeyince her şey çok zor oluyor. Burada en azından dışardaki o problem yok (Ç5)." şeklinde açıklamaktadır. Gene katılımcıların yarısı yerli akrabalarının olmasını Kızıltepe'ye yerleşme sebebi olarak dile getirmiştir. Akrabalık ilişkilerinin göç sonrası yer tercihinde çok büyük bir etken olduğunu tablodaki verilerden de görüyoruz. Yerli akrabalarının olması (13 katılımcı) veya daha önce buraya yerleşen Suriyeli akrabalarının olması $(8$ katılımcı) sebeplerini Kızıltepe'ye göç etme sebebi olarak gösterenlerin toplam katılımcı sayısı 21'dir. Bu sayı Suriyeli katılımcıların \%81'e yakınının akrabalık ilişkisi üzerinden Kızıltepe'ye yerleştiğini bize göstermektedir. Buradaki akrabalık ilişkisi hem manevi hem de maddi açıdan burada kalmalarında etkilidir. Bu konuda çocuklardan ikisi görüşlerini “Akrabalarımız buradaydı. Onların yanına geldik. Kızıltepe' nin bir köyünde sulama işi ile uğraştık bir süre onların yanında (Ç18).", “Akrabalarımız da burada olduğu için burada kalmayı tercih ettik. Başka şehirlere gitmememizin nedeni buydu (Ç4).” şeklinde ifade etmiştir.

Kızıltepe'ye yerleşmede yukarıdaki sebeplerin yanında aileden birinin çalışacak bir iş bulması, kalacak bir ev bulmuş olmak, Kızıltepe'nin Suriye'ye sınır komşusu olması veya Kızıltepe'de bir arkadaşının olması diğer sebeplerdendir.

\subsubsection{Kızıltepe'de yaşayan Suriyelilerin geleceğe yönelik planları}

Burada Suriyelilerin başka ülkelere gitme gibi bir planları olup olmadığını, Suriye’ye geri dönme ile ilgili fikirlerini veya burada kalmaya dair görüşlerini ifade edilmiştir.

Tablo 8. Kızıltepe'de Yaşayan Suriyelilerin Geleceğe Yönelik Planları

\begin{tabular}{lccc}
\hline Görüşler & Çocuk & Veli & Frekans \\
\hline Başka bir ülkeye gitmeyi planlıyorum & 9 & 2 & 11 \\
Burada kalmayı planlıyorum & 6 & 2 & 8 \\
Savaş bitene kadar burada kalmayı planlıyorum & 2 & 0 & 2 \\
Bir planım yok & 3 & 2 & 5 \\
\hline
\end{tabular}

Tablo 8'de görüldüğü üzere Kızıltepe'de yaşayan Suriyelilerin neredeyse yarısı başka bir ülkeye gitmeyi planladıklarını ifade ediyor. Çocukların 4'te 3'ü ile velilerin 3'te 2'si bir daha Suriye'ye dönmeyeceklerini ifade etmişlerdir. 26 katılımcıdan sadece iki çocuk savaştan sonra memleketlerine dönmeyi planladıklarını ifade etmiştir. Bu durumu çocuklar "Suriye'ye dönmek istiyorum ve Arapça bir eğitim almak istiyorum (Ç6).”, “Okuyacă̆ım. Ve Suriye’ye dönene kadar burada kalacağım. Babam dönmek istiyor ama bilmiyorum. Savaş biterse belki döneriz (Ç2). ” şeklinde ifade etmiştir.

Tablo 8'den de görüleceği üzere Suriyeli katılımcıların yarısına yakını başka bir ülkeye gitmek istediklerini ifade etmiştir. Bunun yanında 3'te 2'sine yakını ise Türkiye'de kalmayı planladı̆̆ını ifade etmiştir. Türkiye'de kalmak isteyen çocuklardan ikisi aileleri geri dönse bile kendilerini 18 yaşına 
geldikten sonra buraya geri döneceklerini ifade etmesi çocukların burayı ne kadar benimsediklerini göstermektedir. Çocuklardan biri bu durumu "Ben burada kalmak istiyorum ama babam Suriye'ye gitmek istiyor. Ĕ̆er babam beni götürürse 18 yaşına geldiğimde geri buraya geleceğim (Ç14)." şeklinde dile getirmiştir.

Tabloya göre, çocuklardan 3'ü ve velilerin 2'si ise herhangi bir planı olmadığını dile getirmiştir. Plan yapmamayı haklı bir nokta olarak gören katılımcilardan birisi bu durumu "Bir planım yok. Ne olacağını bilmiyoruz. Plan yapmadım geleceğim için. Ama sanırım sivil toplum alanında çalışacağım. Hayatın bize ne getireceğini bilmiyoruz. Ben hep Şam'da üniversiteye gidip okuyacağım diyordum. Orda hayatımı kuracağım. Ama şimdi buradayım. Bütün dünyada olabileceğimi düşünürdüm de Türkiye'ye geleceğim ve burada okuyacă̆ım aklımın ucundan geçmezdi. Okuma listemde 10 tane ülke vardl. Içinde Türkiye yoktu mesela ama şu an buradayım. O yüzden plan yapmıyorum pek (Ç12)." şeklinde ifade etmektedir.

\subsubsection{Suriyelilerin yaşadıkları genel problemler}

Tabloda Kızıltepe'de yaşayan Suriyeli veli ve çocukların genel olarak yaşadıkları problemler verilmiştir.

Tablo 9. Suriyeli Veli ve Çocukların Yaşadıkları Genel Problemler

\begin{tabular}{lccc}
\hline Görüşsler & Çocuk & Veli & Frekans \\
\hline Suriyeli Olma Üzerinden yargılama/Önyargı & 16 & 5 & 21 \\
İletişim sorunu & 17 & 0 & 17 \\
Yalnızlık & 12 & 4 & 16 \\
Yabancılık & 12 & 3 & 15 \\
İşsizlik & 5 & 1 & 6 \\
Vatandaşlık kimliğinin olmaması & 4 & 2 & 6 \\
Barınma sorunu & 2 & 2 & 4 \\
Beslenme, giyim veya ev eşyası eksikliği & 2 & 0 & 2 \\
Sağlık Sorunu & 1 & 1 & 2 \\
Herhangi bir sorunumuz yok & 1 & 1 & 2 \\
\hline
\end{tabular}

Tablo 9'daki verilere göre çocukların ve velilerin büyük çoğunluğunun en önemli olan sorununun Suriyeli olma üzerinden var olan önyargılar ve bu önyargılarla yargılanma ve tanımlanmadır. Özellikle çocuklar kendilerine isimleri ile hitap edilmediğini, kendilerine "Suri" diye hitap edildiğini ve bu etiketlenmeyle birlikte farklı hakaretler de geldiğini ifade etmektedirler. $\mathrm{Bu}$ durumu çocuklardan bazıları; "ismimizle hitap edilmemesi başka bir sorun. Bize genellikle "Suri”" diyorlar (Ç1).", "En kötü yanı sanırım Suriyeli olmanın başl başına bir etiket olmast. Yani ne kadar iyi olursanız ne kadar temiz olursanı veya arkadaş canlısl, Suriyeli kimliğiniz bütün bunların önüne geçebiliyor. Bu en önemli sorun bence (Ç3)." ,"Illk geldiğimiz zamanlar tabi o zamanlar Suriyeliler yeni yeni geliyordu buralara. Burada yaşayan insanlar o zaman çok kötü davranıyorlardl. Iyi olanlar vardı ama kötüler daha çoktu. Yani o zaman çevremde olanlardan bahsediyorum. Mesela evden çıkarken bizi böyle parmakla gösteriyorlardı. Bak Suriyeli, Suriyeli diye. Arkamızdan böyle çocuklar koşuyor (Ç4)." şeklinde dile getirmişlerdir. Benzer bir durumu ve bu durumla karşılaştığında hissettiklerini bir veli "Onları unutamayı. Yani yıllardır buradayız ama hala bize yabancı gözüyle ve kötü baklyorlar mesela buradakiler. Hala "Suri Suri" diyorlar. Vallahi bizi ne Müslüman ne de Kürt olarak saylyorlar. Öyle değil mi? Yani daha düzgün bir dille bize selam vermemişler. Yani biz onlara bir selam verdiğimizde de düzgün bir şekilde cevabını veya karşılığını alamıyoruz. Kaç yıl oldu buraya geleli hala aynı şekilde davranıyorlar. Insan iki günlük misafirlikte bile birbirini tanımaya başlar. Biz yıllardır buradayız hiçbir şey anlamadik daha. Bu da Allah'ın işi işte (V1)." şeklinde ifade etmiştir.

Tablo 9'da dikkat çeken bir diğer nokta ise iletişim de yaşadıkları sorun ile ilgili. 20 çocuktan 17'si iletişim sıkıntısı yaşadığını ifade ederken velilerden hiçbiri bu sorunu dile getirmemiştir. Bunun temel sebebi ise çocukların okullarda Türkçe ile eğitim görmeleri ve Türkçeyi yeterince bilmemeleridir. Dışarda ise genellikle Kürtçe ile iletişim kurulduğu için çok fazla problem yaşamamaktadırlar. Veliler 
genel olarak dışarı ile iletişim halinde oldukları için iletişim konusunda bir problem yaşamamaktadırlar. Okula veli ziyaretine gittiklerinde de Kürtçe bilen hocaların veya öğrencilerin tercümanlığıyla bu sıkıntının ortadan kalktığını ifade etmişlerdir. Yukarıdaki sorunların yanında, toplumda yabancılık ve yalnızlık çekme, işsizlik, vatandaşlık kimliğinin olmaması, barınma sorunu ve sağlık sorunları Suriyelilerin yaşadığı diğer sorunlardır.

\subsubsection{Yaşanan sorunların giderilmesine yönelik çalışmalar}

Yaşanan sorunların giderilmesine yönelik olarak yapılan çalışmaları incelediğimizde sosyal uyum çalışmalarının yanında yardım çalışmalarının da ön plana çıktığını görmekteyiz. Bu kapsamda ihtiyaç durumlarının tespit edilmesi, gıda, giyim ve kırtasiye desteği veya para yardımı gibi pek çok alanda yürütülen çalışma olduğunu yaptığımız görüşmeler doğrultusunda söyleyebiliriz. Aşağıdaki tabloda Suriyelilerin genel olarak yaşadıkları problemlerin çözülmesi için il-ilçe yöneticileri ile STÖ’lerinin yaptıkları çalışmalara dair görüşleri yer almaktadır.

Tablo 10. Yaşanan Sorunların Giderilmesine Yönelik Çalışmalar

\begin{tabular}{lccc}
\hline Görüşler & İl-İlç Yön. & STÖ & Frekans \\
\hline Sosyal uyum çalışmaları & 2 & 2 & 4 \\
İhtiyacı olan aileleri tespit etme & 2 & 1 & 3 \\
Gıda, giyim veya kırtasiye desteği & 1 & 2 & 3 \\
Suriyeli aileleri ziyaret etme & 2 & 1 & 3 \\
Para yardımı veya yardım kampanyaları & 1 & 2 & 3 \\
Koordinasyon Çalışmaları & 2 & 1 & 3 \\
Valilik veya kaymakamlıkta yapılan & 1 & 1 & 2 \\
toplantılarda konuyu gündeme getirme & 2 & 0 & 2 \\
Okuma yazma kursları & 2 & 2 & 2 \\
Bilgilendirme ve yönlendirme & 0 & 1 & 1 \\
çalışmaları & 0 & & \\
Psikolojik destek & & & \\
\hline
\end{tabular}

Kızıltepe ilçesinde yaşayan Suriyelilerin yaşadıkları genel sorunların giderilmesine yönelik olarak bazı çalışmaların yapıldığı Tablo 10'da görülmektedir. Tabloya göre görüşme yapılan STÖ'lerin 2'si (S1, S2) ve ile her iki il-ilçe yöneticisi, Suriyelilerin toplumdaki sorunlarının çözülmesinin ancak ve ancak sosyal uyumun gerçekleşmesi ile mümkün olduğunu ve bunu çözüme giden en temel noktalardan biri olarak gördükleri için de bu alanda çalışmalar yaptıklarını ifade etmişlerdir. STÖ'lerden bu alanda yaptıkları çalışmaları "Bizim çalışma yelpazemiz baya geniş ama temel de iki noktadan açıklayabiliriz. Birincisi sosyal uyumu gerçekleştirmek ikincisi ise korumaya yönelik çalışmalar. Sosyal uyum kapsamına neler yapıyoruz. Mesela her iki grubun arasındaki diyaloğu gerçekleştirecek çalışmalar yaplyoruz. Yine bu kapsamda meslek edindirme kurslarl, kapasite geliştirme eğitimleri sosyo-kültürel alanda geliştiren eylem ve planlar, sosyalleşmelerini sağlayan çalışmalar, farkındalık çalışmaları, seminerler, ĕgitimler, destekler, kit desteği veriyoruz. Tercüman desteği veriyoruz. Ĕ̈itime yönelik ise, okula gitmeyenleri tespit edip yönlendirme çalışması yapıyoruz. Bunu koruma kapsamında yapıyoruz.

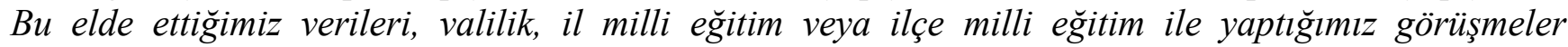
çerçevesinde paylaşıp dile getiriyoruz (S1)." şseklinde ifade etmiştir. Yine her iki yönetici ve STÖ'lerinden 1'i (S1) ihtiyacı olan aileleri tespit etmenin öneminden bahsedip bu alanda çalışma yaptıkları ifade etmişleridir. Bu ihtiyaçları tespit etmek amacıyla yöneticilerin ikisi ve STÖ'lerden 1'i (S3) ev ziyaretleri yaptıklarını ifade etmişlerdir. Yapılan tespitler sonucunda yöneticilerden 1'i(Y6) ve STÖ'lerden 2'si (S3, S4) gıda, giyim veya kırtasiye bazına bu ailelere destek verdiğini, yine STÖ'lerden 2'si (S3, S4) yardım kampanyaları düzenlediklerini, yöneticilerden 1'i (Y6) de para yardımında bulunduklarını ifade etmişlerdir.

Tablo 10'a göre STÖ’lerden biri ve yöneticilerin ikisi de koordinasyon sorunları çözmek için koordinasyon çalışmaları yürüttüklerini, ayrıca bir yönetici (S2) ve bir STÖ (S1)'ü, valilik ve kaymakamlıkta yapılan toplantılarda bu konuyu gündeme getirdiklerini ifade etmişlerdir. İl ve ilçe 
yöneticilerinin ikisi de okuma azma kursları verdiklerini ve bu alanda daha fazla kişiye ulaşılması için farklı çalışmalar üzerine projeler ürettiklerini belirtmişlerdir. $\mathrm{Bu}$ sorunların çözülmesine dair STÖ’lerden ikisi bilgilendirme ve yönlendirme çalışması yaptıklarını, bu sayede sı̆̆ınmacıların sorunlarını çözmek için doğru adrese hızlı bir şekilde ulaşabildiklerini ifade etmişlerdir. STÖ'lerden 1'i (S2) de bünyesinde psikolog bulundurduğunu ve bu sayede sığınmacılara psikolojik olarak destek olabildiğini ifade etmişlerdir.

Kızıltepe'de hayatını sürdüren Suriyeli mültecilerin birçok alanda sıkıntı yaşadıkları yukarıdaki verilerde görülmektedir. Bundan sonraki bölüm de ise araștırmanın temel noktası olan Suriyeli çocukların eğitim durumları ve eğitim sürecinde yaşadıkları sorunlara dair verileri inceleyeceğiz.

\subsection{Kızıltepe’de Eğitimine Devam Eden Suriyeli Çocuklara Yönelik Bulgular}

Bu başlık altında Kızıltepe'de yaşayan ve burada eğitimine devam eden Suriyeli çocukların okullardaki durumlarına, karşılaştıkları problemlere, bu problemlerin çözümüne dair Öğretmen, koordinatör ve yöneticilerin aldıkları tedbirlere, Suriyeli çocukların ve ailelerin eğitimleri noktasındaki talep ve beklentilerinin neler olduğu ve okullarda bu sorunların çözümüne dair il yöneticileri, okul yöneticileri, koordinatör ve öğretmenlerin önerilerine ilişkin elde edilen veriler alt başlıklar halinde sıralanmıştır.

\subsubsection{Suriyeli çocukların okulda yaşadıkları sorunlar}

Kızıltepe'de eğitimlerine devam eden Suriyeli öğrencilerin okullarda yaşadıkları sorunlara ilişkin Suriyeli velilerin, çocukların ve koordinatörlerin, öğretmenlerin ve okul yöneticilerini görüşleri aşağıdaki tabloda verilmiştir. Görüşler doğrultusunda en temelde dil probleminin yaşandığ 1 ve diğer problemlerin de çoğunlukla bu dil problemlerine bağlı olarak gerçekleştiğini görmekteyiz.

Tablo 11. Okulda Yaşanan Sorunlara Dair Katılımcıların Görüşleri

\begin{tabular}{lcccccc}
\hline Görüşler & Çocuk & Veli & Öğrt. & koor. & Yön. & F \\
\hline Dil(iletişim) Sorunu & 18 & 5 & 5 & 3 & 4 & 35 \\
Derslerde başarısızlık/anlamada güçlük & 10 & 1 & 4 & 1 & 4 & 20 \\
Dışlanma/Önyargılar & 8 & 1 & 1 & 3 & 2 & 15 \\
Öğretmenlerin ilgisiz olması/Göz Ardı & 3 & 6 & 1 & 2 & 0 & 12 \\
Edilme & 3 & 1 & 1 & 0 & 5 & 10 \\
Okul kültürüne uyum sorunu & 5 & 1 & 0 & 1 & 1 & 8 \\
Kaynaklara Ulaşma (Roman-öykü-ş̧iir- & 3 & 0 & 0 & 1 & 1 & 5 \\
fikir) & 2 & 1 & 1 & 0 & 1 & 5 \\
Maddi sorunlar & 3 & 0 & 0 & 1 & 1 & 5 \\
Yalnızlık ve sessizlik & 1 & 0 & 1 & 1 & 1 & 4 \\
Yabancılık ve utangaçlık & 2 & 0 & 0 & 1 & 1 & 4 \\
Öğrencilerin Hazırbulunuşluluklarının & & & & \\
tespit edilmeden eğitime dahil edilmesi & & 1 & 0 & 1 & 0 & 2 \\
Yabancı bir sisteme maruz kalmak & 0 & 1 & 0 & 0 & 0 & 1 \\
Suriyeli öğrencilerin notlarının & 1 & 0 & 0 & 0 & 0 & 1 \\
düşürülmesi & 0 & 1 & 0 & 0 & 0 & 1 \\
Psikolojik Sorunlar & & & &
\end{tabular}

Tablo 11'deki verilere göre, okulda yaşanan sorunlardan en çok ön plana çıkanı dil (iletişim) sorunudur. 20 çocuktan $18^{\prime} \mathrm{i}$, 6 veliden 5'i ayrıca araştırmaya katılan öğretmen, koordinatör ve yöneticilerin neredeyse hepsi bu sorunun en öncelikli sorun olduğunu belirtmişlerdir. Çocuklar dil farklılığından dolayı, günlük konuşmada büyük bir sıkıntı yaşamasa da, okuduğunu anlama noktasında hala sıkıntı yaşadıklarını ifade etmişlerdir. Öğretmenler, Koordinatörler ve yöneticiler de bu konuda 
benzer bir durumu ifade edip, bu temel sorunun aslında diğer bütün sorunların kaynağı noktasında olduğunu ifade etmişlerdir. Yöneticilerden biri bu durumu "Dil problemi var. Buna bağll olarak dersi anlamıyor ve aynı zamanda derse odaklanmakta sıkıntı yaşıyor. Bu durum davranışsal ve bilgi noktasında sorunlara yol açıyor. Yani uyum sorunu yaşlyor. Çocuk kendini kanıtlamak için bu sefer farklı davranışlar içerisine giriyor. Derste farklı alanlarla ilgilenme, çocuklarla kavga etme veya gruplaşmalar ortaya çıkan durumların bazıları (Y5)." şeklinde ifade etmiştir. Bu durumu aslında çocukların verdikleri cevaplarda da görebiliyoruz. Çocukların yarısı da en temel sorunlarından birisinin derslerdeki başarısızlık ve anlamada yaşadıkları güçlük olduğunu dile getirmişlerdir. Çocuklardan biri bu durumu "Dili anlamama problemi çok fazladır. Konuşmada artık çok büyük sıkıntı yaşamasam da anlamada hala güçlük çekiyorum. Çok az anllyorum. \%70'ini anlamıyorum tahminen. Yani çok az kısmını anlıyorum okuduğumun. O yüzden derslerde sıkılıyorum ve bu yüzden okulun çoğu zamanı aslında sıkılmak anlamına geliyor (Ç17)." şeklinde ifade etmiştir.

Dil sorunu çocukların okul tercihlerinde de etkili olmaktadır. Suriyeli öğrencilerin çoğu imam hatip liselerinde öğrenimlerine devam etmektedirler. Bunun temel sebebi ise imam hatip liselerinde Arapça dil eğitiminin verilmesi ve bu okullarda bazı derslerin Arapça olmasıdır. Bu konuda çocuklardan biri durumu "Mesela benim imam hatip lisesini tercih etmemin nedeni burada Arapça dil eğitiminin de verilmesidir. Burada hem Arapçayı ögreniyorum hem de derslerde daha başarıll olabiliyorum. Bu okulda daha başarılı olmamın tek sebebi Arapçayı biliyor olmam. Birçok arkadaşım da bu yüzden imam hatip liselerini tercih ettiler (Ç18)" sözleriyle ifade etmiştir.

Tabloya göre katılımcılardan 15'i Suriyeli öğrencilerin yaşadıkları sorunlar arasında dilin yanında dışlanma ve önyargı olduğunu da ifade ettiler. Burada özellikle bu dışlanma ve önyargıların neticesinde bir Suriyelileri bir kalıba sokma durumunun olduğunu ve bunların sosyal yaşamlarında çok fazla karşılarına çıktığını bir öğrenci "Mesela arkadaşlar arasında sıkıntı yaşıyorum. Sevemiyor, kabullenemiyor, paylaşımda bulunmuyor. Senin ikametine baklyor mesela, içtiğin sigaraya veya giyimine ve telefonuna baklyor. Onunkinden iyi ise ya sen mi Suriyelisin ben mi diye bir cümle kullanabiliyor. Mesela çok kolay bir şekilde Suriyelisin sen nasıl iphone kullanabiliyorsun diye şaşırarak sorabiliyor. Mesela özelikle o vatandaşlık verileceği ile ilgili haberler çıktığ zaman çok tepki alıyorduk. Sanki bizim elimizdeymiş gibi. Devletin yaptığı bir şeyin tepkisini de biz alıyorduk. Seni vatandaş etmeyeceğiz, toprağımızı paylaşmayacă̆ız vs. gibi hiç alakamızın olmadığı durumlarla karşılaşıyoruz. Ya mesela bir kadını sevemiyorsun, sevdiğin zaman Suriyeli olduğun için her zaman ikinci veya üçüncü planda oluyorsun. Seni kabullenmiyor. Yarın sen buradan çekip gidebilirsin diyor. Ailen istemez sen Suriyelisin diyor. Daha çıkmamışsın sevgili olmamışsın evliliğe getiriyor. Anladığım kadarlyla bir önlem allyor kendince. Ama kız Suriyeli olunca yaşamak daha kolay oluyor. Kadınlar da buralı biriyle evlensem kimlik alırım, haklara sahip olurum diye baktığı için o ilişkiler daha rahat olabiliyor (Ç12)" ş̧eklinde ifade etmiştir. Bu önyargılarla beraber sorunların artığını ve farklı durumların ortaya çıkabildiğini ifade eden bir veli oğlunun okula bir yıl ara verdiğini "Suriyeler" okulunda (Geçici Eğitim Merkezi) iken daha iyiydi. Çünkü dilini biliyorlardı ve hocaları da bizim orallydılar. Haliyle burada anladikları bir dilde ve kendilerine yakın olan hocalar tarafindan ders gördükleri için sıkıntı yoktu. Sonrasında Suriyeliler okulu kapanınca çocuklar Türkiye'ye okullarına gittiler. Küçükler çok zorlanmadılar ama lise ve ortaokuldakiler için çok zordu. Hatta lisedeki oğlum 1 yıl okula ara verdi. Çünkü dersleri anlamıyordu ve çocuklar ona kötü davranıyorlardı. Bunu kaldıramadı (V6)" sözleriyle dile getirmiștir. Bu sorunların yanında öğretmenlerin ilgisizliği veya Suriyeli öğrencilerin göz ardı edilmesi, okul kültürüne uyum, gerçek anlamda anlayabilecekleri kaynaklara(Arapça roman, öykü vb.) ulaşamama sorunu, maddi sorunlar, yalnızlık, yabancılık, utangaçlık, başarısızlık, sessiz olma ve psikolojik sorunların öğrencilerin yaşadıkları diğer sorunlardır.

\subsubsection{Okulda yaşanan sorunların giderilmesine yönelik alınan tedbirler}

Okulda yaşanan sorunların giderilmesine yönelik olarak alınan tedbirler daha çok öğrencilerin okula uyum sağlamalarını hızlandıracak ve öğrenciler ile okul arasındaki bağı güçlendirecek çalışmalar olduğunu görmekteyiz. Kızıltepe'de eğitimine devam eden Suriyeli çocukların okullarda yaşadıkları sorunların giderilmesine yönelik öğretmenlerin, koordinatörlerin ve okul yöneticilerinin aldıkları tedbirlere ilişkin görüşleri aşağıdaki tabloda verilmiştir. 
Tablo 12. Okulda Yaşanan Problemlerin Giderilmesine Yönelik Alınan Tedbirler

\begin{tabular}{lcccc}
\hline Görüşler & Ö̆̆grt. & Koor. & Yön. & F \\
\hline Okuma-Yazma çalışmaları & 3 & 3 & 5 & 11 \\
Etkinliklere katılımlarını sağlama & 3 & 1 & 5 & 9 \\
Oryantasyon(uyum) çalışmaları & 3 & 0 & 5 & 8 \\
Öğrencilerle ekstra zaman harcama & 3 & 1 & 2 & 6 \\
Ailelerle Görüşmeler & 1 & 3 & 1 & 5 \\
Akran danışmanlığı & 1 & 2 & 0 & 3 \\
Diğgr öğrencilerden empati kurmalarını isteme & 0 & 0 & 1 & 1 \\
\hline
\end{tabular}

Yukarıda Tablo 12'ye göre, öğretmenlerin yarısı, koordinatörlerin ve okul yöneticilerinin tamamı Suriyeli çocukların yaşadıkları problemleri çözmek için en temelde okuma-yazma çalışmaları yaptıklarını ifade etmişlerdir. Öğretmenlerin 3'ü sınıf içi ve dışı etkinliklerde ve oyunlarda göç ile gelen öğrencilere sürekli görev verdiklerini, dahil olabilecekleri etkinlikler seçtiğini ve diğer öğrencilerin onlarla birlikte oyunlar oynaması için direktifler verdiğini ve empati kurmaları gerektiğini ifade ederken, okul yöneticilerinin tamamı bu yönde çalışmalar yapılması için öğretmenlerle koordineli bir şekilde çalışmalar yürüttüklerini ifade etmişlerdir. Bir öğretmen bu konudaki görüşlerini “ $O k u l$ yönetimi ve öğretmenleriyle yaptığımı toplantıda göç eden öğrencilere normal ĕgitim öğretim programının yanında özel sinıflarda öncelikle Türkçe dilinin ögretilmesinin yanında öğrencinin seviyesine uygun diğer derslerde de ĕgitimin verilmesi kararı aldık. Ĕ̈itsel açıdan da öğrencilerin ögrenmiş olduğu öğrenmeleri uygulamada göstermesini sağlamak içinde rahat bir ortamin oluşturulmasıyla hem öğrendiklerini tekrar edip pekiştirmesini hem de özgüvenini yükselterek kendini toplumda bir birey olarak görmesini sağlamak için etkinlikler yaptık. Okul dışı zamanlarında da devletin kamu kurumlarında sosyo kültürel ve spor gibi aktivitelere de yönlendirip kişinin ortama uyum săglaması ve öğrenmelerini artırıcı etkiye sahip olması için etkinliklerde yer almasını să̆ladık (Ö3)" şeklinde ifade etmiştir. Ayrıca oryantasyon çalışmaları, ailelerle görüşme ve akran danışmanlığı gibi noktalarda çalışmalar yürütülmektedir.

\subsubsection{Suriyelilerin eğitimlerine yönelik talep ve beklentileri}

Suriyelilerin eğitimlerine yönelik talep ve beklentilerini incelediğimizde yaşadıkları sorunların çözümü doğrultusunda olduğunu görüyoruz. Bu kapsamda en çok sıkıntı yaşadıkları dil problemi öne çıkmakta ve bu konuda ek çalışmalar yapılması gerektiğini ifade etmektedirler. Bunun dişında kendi anadilleri olan Arapça 'nın öğretilmesi de ön plana çıkan bir başka taleptir. Üzerinde durulması gereken noktalardan bir tanesi ise Suriyelilerin geleceklerine yönelik olarak içinde bulundukları belirsizlik olduğunu söyleyebiliriz. Bu noktada gelecekleri ile ilgili belirsizliğin ortadan kaldırılması ve ne olacaklarına dair durumun netleşmesi için gerekli çalışmaların bir an önce bir neticeye varmasını istemeleri de ön plana çıkan talepleri arasında yerini almaktadır. Bu durum onların geleceklerini inşa etme sürecinde karar almalarını zorlaştıran bir durum olduğu için kendileri açısından karmaşa yaratan bir noktaya dönüşmüş durumdadır. Bu karmaşanın bir an önce giderilmesi, onların da ona göre bir yol çizmelerini sağlayacaktır. Suriyeli velilerin ve Kızıltepe'de eğitimine devam eden Suriyeli öğrencilerin eğitimleri noktasında yetkililerden talep ve beklentilerine ilişkin görüşleri tabloda verilmiştir.

Tablo 13. Suriyelilerin Eğitimlerine Yönelik Talep ve Beklentileri

\begin{tabular}{lccc}
\hline Görüşler & Çocuk & Veli & F \\
\hline Türkçeyi daha iyi öğrenmek için ek çalışmalar & 6 & 3 & 9 \\
Gelecek için iyi bir eğitim almak & 6 & 2 & 8 \\
Belirsizliğin ortadan kaldırılması / Biz ne olacağız & 3 & 4 & 7 \\
Suriyeliler için okulların açılması / Eğitim dilinin & 5 & 0 & 5 \\
Arapça olması & 0 & 3 & 3 \\
Çocuklar arasında eşitliği sağlasınlar & 2 & 0 & 2 \\
Maddi sorunların (giyim, araç-gereç) giderilmesi & &
\end{tabular}


Eğitimlerin sürekliliğinin sağlanması

Bürokratik işlemlerin (Resmi belge isteme) azaltılması/

Bilgilendirme çalışmaları yapmaları

$2 \quad 0 \quad 2$

Okullarda Suriyelilere kontenjan ayrilması

20

2

Tablo 13'e göre, eğitimlerine yönelik yetkililerden talep ve beklentilerinin neler olduğu noktasında fikirleri alınan Suriyeli 7 çocuk ve 3 Veli Türkçeyi daha iyi öğrenmek için ek çalışmalar yapılması gerektiğini ifade etmişlerdir. Bazı okullarda yürütülen çalışmaların eksik olduğunu bu yüzden standart bir sistem çerçevesinde çalışmaların yürütülmesi gerektiğini ifade etmişlerdir. Bir öğrenci bu konudaki fikrini "Iyi bir eğitim olsun istiyorum yani gelecekte işime yarayacak beni bir yerlere getirecek bir ĕgitim istiyorum. Bu şekilde bir yandan dil ögrrenmeye adapte olmaya çalışırken, diğer dersler sekteye uğruyor ve ikisi de yarım yamalak kalıyor. Ek çalışmalar yapılmalı dil öğrenimi ile ilgili. Bir de günde en azından 2 saatin dil öğretimine ayrılması gerektiğini düşünüyorum (Ç18)" sözleriyle ifade etmiştir. Eğitime devam eden çocukların tamamı eğitimi bir umut olarak görmektedirler. Çocuklardan 6'sı ve velilerden 2'si gelecekleri için iyi bir eğitim almak istediklerini ifade etmişlerdir. Çocuklardan biri (Ç4) burada kalmayı düşünmediğini ama kalanlar için iyi kurgulanmış ve en az iki dili öğretecek şekilde bir eğitim verilmesi gerektiğini ifade etmiştir. Bunun yanında bazı öğrencilerin beklentilerini ifade edip, bu beklentilerinin karşılanmayacağına dair umutsuzluğunu "Bizim iyiliğimiz için olacak olan, daha düzgün, daha düzenli ve ileride işimize yarayabilecek daha evrensel normlarda bir eğitim istiyorum. Yetkililerden bir talebim yok çünkü talebim olsa bile samimi olunmadiğ $l$ için yerine getirilmeyeceğinden eminim (Ç8)" sözleriyle ifade etmiştir. Bir veli de bu konuda beklentisini "Çocuklarımın kendi ayaklarl üstünde duracakları bir konuma gelmelerini istiyorum. İnsanlı̆̆a ve kendilerine hayırlart olsun istiyorum. Bu yüzden okumalarını istiyorum. Iyy bir ĕgitim alsınlar istiyorum. Öyle iyi olsun ki bu eğitim bu kötü durumun bizim çocuklarımıza bir şans olarak dönmesini istiyorum (V3)" sözleriyle dile getirmiştir.

Tabloya göre 5 katılımcı sadece Suriyelilerin okuduğu bir okulda ve Arapça dilinde eğitim almak istediğini ifade etmiştir. Bu öğrencilerin bazıları (Ç3, Ç9) Türkçe' nin iyi öğretilmesi ve okullarda ayrımcılık olmadığı taktirde bu sistemde de okuyabileceğini ancak bu şartlar sağlanamayacaksa sadece Suriyelilerin olduğu Arapça dilinde eğitim almak istediğini belirtmiştir. Diğer öğrenciler (Ç14, Ç13, Ç5) ise Arapça eğitim almak istediklerini ve temelde bu dilin öğretilmesi gerektiğini yanında Türkçe olabileceğini ifade etmişlerdir. Bu konuda çocuklardan biri fikrini "Arapça bir eğitim almak istiyorum. Arapçanın yanında Türkçe verilebilir ama temelde Arapça olmall. Bir de bize artık ne olacağl netleştirilse ona göre belki biz de bir şeyleri daha net kararlaştırabilir veya isteyebiliriz. Hocalar Arapça bilseydi iyi olurdu. Ne bileyim okuyacak Arapça kitap bulamıyoruz mesela, kendi okulumu olsa bu konuda bence daha çok destek gelir. Suriyeliler okulunda okumak isterdim (Ç13)" sözleriyle dile getirmiştir.

Tablodaki bilgilere göre, velilerden 3'ü (V1, V2, V5) okullarda çocukları ile diğer çocuklar arasında uygulamalarda farklılıklar bulunmaması ve eşit koşullarda okumaları gerektiğini belirtmiştir. $\mathrm{Bu}$ durumun herkes tarafından net bir şekilde bilinmesi adına bir veli beklentisini "Çocuklar arasında ayrım yapılmamasını istiyoruz. Bu konuda çok katı kurallar getirilmeli okullarda. Herkesin (öğretmen, idare, halk) tabi olacağ l net kurallar. Herkes bilmeli ki bu insanlar keyfinden buraya gelmedi o yüzden bunların çocuklarının da artık buradakilerden bir farkının olmadığı, onlarla eşit şartlara sahip olması gerektiği net olmalı (V2)" sözleriyle ifade etmiştir.

Tabloya verilen bilgilere göre maddi sorunlar yaşayan 2 çocuk bu konuda duruma el atılması gerektiğinin ve maddi sorunların giderilmesi (özellikle liselerde servis ücretleri) gerektiğini ifade etmişlerdir. Eğitimin sürekliliğinin devam etmesi gerektiğini belirten bir çocuklardan ikisi, standart bir şeye artık varılması gerektiğini ve okul değiştirmekten sıkıldıklarını ifade etmişlerdir. Çocuklardan biri Suriyelilerin uğraşması gereken bürokratik işlemlerin azaltılması gerektiğini ve Suriyelilerin okula kayıtlarının kolaylaştırılması gerektiğine yönelik görüşlerini "Bu konuda Suriyelilere yönelik daha açık ve olumlu noktalar oluşturacak bir sistem gerekli. Mesela mahallemizde olan bir erkek arkadaş belge istendiği için okula devam edemiyor. Illk zamanlar belgeye gerek yoktu ama şu anda liseye kayıt için belge istiyorlar. Arkadaşım da Suriye’ye gidemediği için (giderse askere alınacak) belgelerini getiremiyor dolayısıyla okula kaydını yapamıyor (Çl)“ sözleriyle dile getiriyor. Ayrıca çocuklardan 
2'si aynı koşullarda olmadıkları için aynı sınava tabi tutulmalarının doğru olmadığını ve liselerde Suriyelilere ayrı kontenjanlar ayrılması gerektiğini ifade etmişlerdir.

Yapılan görüşmeler neticesinde Suriyelilerin eğitimlerine yönelik bir dizi talep ve beklenti içinde oldukları görülmüştür. Bu talep ve beklentilerden bazıları; Türkçeyi daha iyi öğrenmek için ek çalışmalar yapılması, gelecek için iyi bir eğitimin kurgulanması, çocuklar arasında eğitimin sağlanması ve eğitimin sürekliliğinin sağlanmasıdır. Bu talep ve beklentilerin Tablo 10'da yapılan çalışmalarla uyumlu olduğu görülmektedir. Ancak bu taleplerin mülakatlarda bu kadar belirgin olması yapılan çalışmaların eksik kaldığını göstermektedir.

Araştırma kapsamında ortaya çıkan veriler en temel sorunun dil olduğunu ortaya koyuyor. Bu çerçevede Suriyeli çocukların ve velilerin eğitim dili olarak tercih ettikleri dilin hangisi olduğuna yönelik veriler elde edilmiştir. Katılımcı çocuklar ve veliler 1. Ve 2. Dil tercihlerini tablodaki gibi sıralamıştır.

Tablo 14. Suriyeli Çocukların ve Velilerin Eğitimlerindeki Dil Tercihleri

\begin{tabular}{|c|c|c|c|c|c|c|c|c|c|c|c|c|c|c|c|c|c|c|c|c|}
\hline Diller & $\begin{array}{l}\text { Ç } \\
1\end{array}$ & $\begin{array}{l}\text { Ç } \\
2\end{array}$ & $\begin{array}{l}\text { Ç } \\
\mathbf{3}\end{array}$ & $\begin{array}{l}\text { Ç } \\
\mathbf{4}\end{array}$ & $\begin{array}{l}\text { Ç } \\
\mathbf{5}\end{array}$ & $\begin{array}{l}\text { Ç } \\
6\end{array}$ & $\begin{array}{l}\text { Ç } \\
7\end{array}$ & $\begin{array}{l}\text { Ç } \\
\mathbf{8}\end{array}$ & $\begin{array}{l}\text { Ç } \\
9\end{array}$ & $\begin{array}{l}\text { Ç } \\
\mathbf{1 0}\end{array}$ & $\begin{array}{l}\text { Ç } \\
\mathbf{1 1}\end{array}$ & $\begin{array}{l}\text { Ç } \\
12\end{array}$ & $\begin{array}{l}\text { Ç } \\
\mathbf{1 3}\end{array}$ & $\begin{array}{l}\text { Ç } \\
14\end{array}$ & $\begin{array}{l}\text { Ç } \\
15\end{array}$ & $\begin{array}{l}\text { Ç } \\
16\end{array}$ & $\begin{array}{l}\text { Ç } \\
17\end{array}$ & $\begin{array}{l}\text { Ç } \\
18\end{array}$ & 19 & $\begin{array}{l}\text { Ç } \\
20\end{array}$ \\
\hline Arapça & & 1. & 1. & 1. & 1 & & 1. & & 1. & & & 2. & 1. & 2. & 2. & & & 1. & & 1. \\
\hline Türkçe & 1. & 2. & & & 2 & 2. & & 1. & 2. & 2. & 1. & & 2. & & 1. & & 1. & 2. & & \\
\hline Kürtçe & & & & & & & 2 . & 2. & & & & 1. & & & & & & & & 2. \\
\hline İngilizce & 2. & & 2. & 1. & & 1 . & & & & & 2. & & & 1. & & 1. & 2. & & & \\
\hline Diğer & & & & & & & & & & & & & & & & 2. & & & & \\
\hline Diller & V & V & $\mathbf{V}$ & $\mathbf{V}$ & $\mathbf{V}$ & & & & & & & & & & & & & & & \\
\hline Dimer & 1 & 2 & 3 & 4 & 5 & 6 & & & & & & & & & & & & & & \\
\hline Arapça & & 2. & 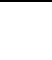 & 2. & 2 & 1. & & & & & & & & & & & & & & \\
\hline Türkçe & & 1. & 1. & & 1 & 2. & & & & & & & & & & & & & & \\
\hline Kürtçe & & & & & & & & & & & & & & & & & & & & \\
\hline İngilizce & & & 2. & 1 . & & & & & & & & & & & & & & & & \\
\hline Diğer & & & & & & & & & & & & & & & & & & & & \\
\hline
\end{tabular}

Tablodaki verilere göre Suriyeli çocukların ve velilerin tercih ettikleri diller Arapça, Türkçe, Kürtçe ve İngilizcedir. 1. Öncelik olarak Arapçayı 9 çocuk, Türkçeyi 5 çocuk, İngilizceyi 5 çocuk ve Kürtçeyi 1 çocuk seçmiştir. Velileri incelediğimizde ise Türkçeyi 3 veli, Arapçayı 1 veli ve İngilizceyi ise 1 veli tercih etmiştir. Tablodan çıkan bu verilere göre dil tercihi açısından hem çocuklarda hem de velilerde farklı eğilimler olduğunu söyleyebiliriz. 1 ve 2 . Öncelikleri göz önünde bulundurursak katılımcıların 16's1 Türkçeyi, 16's1 Arapçayı, 11 İngilizceyi ve 5'inin de Kürtçeyi seçtiği görülmektedir. Verilerde Türkçe ve İngilizcenin oran olarak çok yüksek olduğu dikkat çekmektedir.

\subsubsection{Eğitimde yaşanan sorunların çözümüne yönelik öneriler}

Eğitimde yaşanan sorunların çözümüne yönelik önerileri incelediğimizde Türkçe dil kurslarının artırılması, farklı programların uygulanması, eğitim ihtiyaçlarının karşılanması ve uzmanlar tarafından psikolojik destek sağlanması gibi öneriler ön plana çıkmaktadır. Bu öneriler aslında öğrencilerin günlük yaşamda ihtiyaç duydukları veya eksikliğini hissettikleri durumları da karşımıza çıkarmaktadır. Yapılan görüşmeler neticesinde Kızıltepe'de eğitimine devam eden Suriyeli çocukların eğitimde yaşanan sorunların çözümüne dair öğretmenlerin, koordinatörlerin ve yöneticilerin önerileri aşağıdaki tabloda verilmiştir.

Tablo 15. Eğitimde Yaşanan Sorunların Çözümüne Yönelik Öneriler

\begin{tabular}{lcccc}
\hline Görüş̧ler & Ö̈̆rt. & Koor. & Yön. & F \\
\hline Türkçe dil kursu verilmeli & 4 & 3 & 4 & 11 \\
Farklı programlar uygulanmalı & 3 & 2 & 2 & 7 \\
Eğitim (malzeme, giyim, servis ücreti) ihtiyaçları & 0 & 2 & 2 & 4
\end{tabular}


karşılanmalı

Uzmanlar tarafindan psikolojik destek sunulmalı

Ailelerle görüşmeler yapılmalı

Rehberlik (uyum) çalışmaları artırılmalı

Sosyalleşme çalışmaları (etkinlikler) yapılmalı

Okulda çalışan herkese hizmet içi eğitim verilmeli

Okullara sosyal çalışmacı ve dil bilimci verilmeli

Öğretmenler öğrencilerle ekstra vakit geçirmeli

$\begin{array}{llll}0 & 1 & 3 & 4 \\ 1 & 1 & 2 & 4 \\ 2 & 1 & 0 & 3 \\ 2 & 1 & 0 & 3 \\ 1 & 1 & 1 & 3 \\ 1 & - & 2 & 3 \\ 1 & 0 & 0 & 1\end{array}$

Tablo 15'e göre okulda yaşanan sorunların çözümüne dair önerilerin neler olduğu konusunda fikri alınan 5 öğretmen, 3 koordinatör ve 5 okul yöneticisinin neredeyse tamamı, göç ile gelen Suriyeli çocukların tamamı dil eğitimlerine ağırlık verilmesi gerektiğini belirtmişlerdir. Dil sorunu çözülmediği taktirde göç eden çocukların eğitimden yeterince fayda sağlayamayacağının net olduğunu belirtmişlerdir. Ayrıca var olan dil eğitimlerine ek olarak farklı programlar uygulanması gerektiğini ifade etmişlerdir. Bir koordinatör bu konudaki fikrini "En temelde bu çocukların dili ögrenmesi lazım. Hem bulundukları ortama hızlı bir şekilde uyum sağlamaları için hem de derslerinde başarılı olmaları için. Bunun için hiç ara vermeden dil eğitimleri farkl programlarla desteklenmeli ve en kusa zamanda eğitimde zorluk yaşamayacakları noktaya gelmelerinin sağlanması gerekiyor (K1)" şeklinde ifade etmiştir. Bir öğretmen de bu konudaki görüşünü "Bu ögrencilere ve ailelerine en az bir yıl sürecek sadece dil eğitimi verilmeli. Bununla beraber iki dili bilen ĕgitimcilerin yetişmesi için gönüllü ögretmenleri aynı yoğunlukta dil ĕgitimine tabi tutmak gerekir (Ö1)" sözleriyle dile getirmiştir. Suriyeli çocukların yerli çocuklarla aynı programa tabi tutulup liselere giriş noktasında aynı sınava tabi tutulmasının da bir eşitsizlik yarattığını ve ifade eden bir koordinatör bu konudaki fikrini "Müdüre de dedim. Koordinatörlerine de dedim. Mesela 8. Sinıf ögrenciler için, bu sınav sistemi ile ilgili, yani Suriyeli bir çocuk ile Türkiye'deki bir çocuğun ayn sınava girmesi noktasındaki duruma kesinlikle katılmıyoruz ve doğru bulmuyoruz. En temelde bunun değişmesi gerekiyor. Suriyelilerin biraz daha kolay olması lazım (K1) "şeklinde ifade etmiştir.

Koordinatörlerin 2'si ve yöneticilerin 2'si Suriyelilerin yaşadıkları maddi sorunlara değinerek ailelerin yaşam şartlarının zor olduğunu, temel ihtiyaçlarını gidermede sıkıntı yaşadıklarını ve bu sıkıntılara rağmen çocuklarını okula gönderen ailelere bu noktada yardımcı olunması gerektiğini, en azından çocukların okul masraflarının imkanlar dahilinde karşılanması gerektiğini bunun sağlanması durumunda Suriyelilerin eğitime daha fazla katılacağını dile getirmişlerdir. Bunların yanında uzmanlar tarafından psikolojik destek sunulması, okullarda uyum problemlerini giderecek rehberlik faaliyetlerine ağırlık verilmesi, sportif faaliyetlere ve sosyal etkinliklere öğrencilerin etkin katılımının sağlanması, okullardaki bütün personelin yeterli bilgiye sahip olacak noktaya gelmesi için hizmet içi eğitimlere ağırlık verilmesi, okullarda sosyal çalışmacı ve dil bilimci olmasına yönelik öneriler yapılmıştır.

\subsubsection{Okulun Suriyeli öğrencilere katkıları}

Suriyeli öğrencilere okulun, sosyalleşme, arkadaş çevresinin gelişmesi ve en temel sorunları olan dil bilmeme sorununun çözülmesi gibi pek çok alanda katkıları görülmektedir. Bu durum çocukların çevre uyumunu kolaylaştırmakta ve daha hızlı bir şekilde adapte olmalarını sağlamaktadır. Kızıltepe'de eğitimine devam eden Suriyeli öğrencilere okulun katkılarına dair Suriyeli veli ve çocukların, öğretmenlerin, koordinatörlerin ve okul yöneticilerinin görüşleri aşağıdaki tabloda verilmiştir.

Tablo 16. Okulun Suriyeli Öğrencilere Katkılarına İlişkin Katılımcıların Görüşleri

\begin{tabular}{lcccccc}
\hline Görüşler & Çocuk & Veli & Öğrt. & Koor. & Yön. & F \\
\hline Sosyalleşme Sağlaması & 9 & 4 & 5 & 2 & 3 & 23 \\
Arkadaş çevresinin oluşması & 10 & 4 & 4 & 3 & 1 & 22 \\
Yeni bir dilin (Türkçe) öğrenilmesi & 12 & 3 & 2 & 3 & 2 & 22 \\
Yeni bir çevreye alışmalarını sağlama & 6 & 2 & 1 & 1 & 2 & 12 \\
Psikolojik Sorunlardan Kurtulma & 2 & 2 & 2 & 1 & 3 & 10
\end{tabular}




\begin{tabular}{lllllll} 
Eğitime devam edebilme & 4 & 2 & 1 & 2 & 0 & 9 \\
Aidiyet duygusu kazanma & 1 & 4 & 1 & 1 & 2 & 9 \\
Hayatın devam ettiğini görmek & 2 & 3 & 1 & 0 & 2 & 8 \\
Ülkenin kültürünü tanıma & 5 & 0 & 0 & 0 & 0 & 5 \\
Güvenli bir ortamda hissetme & 0 & 0 & 1 & 0 & 2 & 3 \\
Yok denecek kadar azdır & 0 & 0 & 0 & 0 & 1 & 1 \\
\hline
\end{tabular}

Verilen tabloya göre okulun Suriyeli çocuklara katkısının neler olduğuna dair görüşme gerçekleştirilen Kızıltepe'de eğitimine devam eden çocukların yarısına yakını, okula devam eden çocuğu bulunan velililerin neredeyse tamamı, görüşülen öğretmenlerin tamamı 5 okul yöneticisinin 3'ü ve koordinatörlerin 2'si okulun çocukların sosyalleşmesi açısından önem arz ettiğini, topluma alışmada ve tanımada büyük bir rol oynadığını ifade etmişlerdir. Bir okul yöneticisi bu konudaki fikrini "Uyum okulda başlar. Çocuklar sosyalleşerek bir araya geldiklerinde bu aynı zamanda mahalleye yansır. Okulda kurulan arkadaşlıklar mahallede devam eder. Bu şekilde bütüncül bir durum ortaya çıkar ve mahallelerde de yerel halk ile Suriyeliler arasında bir diyalog oluşur. Buda toplumda kaynaşma sağlar ve uyumlu bir süreç doğurur (Y5)" sözleriyle dile getirmiştir. Yanı sıra çocukların yarısı, velilerin tamamına yakını, öğretmen ve koordinatörlerin neredeyse tamamı ve yöneticilerden 1'i bir çocuğun bulunduğu ortama uyum sağlaması, topluma dahil olması ve sosyalleşmesi açısından edindiği arkadaşlıkların çok önemli olduğunu ifade etmiştir. Çocuklar birbirleriyle oyunlar ve etkinlikler ile bir araya geldiklerinden aralarında bağ kurulması ve bir araya getirilmesi yetişkinlere oranla çok daha yüksektir. Okul ortamının da tam olarak bunu sağladığını ve bu konuda en büyük rolü üstlendiğini ifade etmişlerdir. Öğretmenlerden biri bu konudaki görüşünü "Akranları ile bir arada bulunmak. Her zaman savunduğum şeylerden biridir. Travmada da çok önemli bir durum veya olgudur. Yaşanan problem normal hayata dönmedikçe iyileşmeye çalışmaz. Bir çocuk annesini kaybetmiş olabilir, bir çocuk bir savaştan gelmiş olabilir, onu normal hayata ne kadar hızlı adapte edersek, normal hayatın ne kadar çabuk devam ettiğini görürse, hayatı o kadar yolunda gitmeye başlar. Tabi ki yasını da yaşayacak. Bu göç ile gelen çocuk için de geçerli. Ama akranlart ile bir arada bulunmak ona en iyi gelecek dönem diye düşünüyorum. Yetişkin olsa, yani bizim gibi, biz biraz daha kabuğumuza çekilmeyi seven insanlar olabiliriz. Ama bir çocuğu en çok arkadaşı etkiler. Bu ortamın içinde olmaları onlar için en hayırlısı ve en güzeli diye düşünüyorum. Bir de sosyal davranışlarl öğrenebileceği en iyi yer okul. Sadece iyi anlamda değil. Bir küfür de ögrenebilir veya kavga etmeyi ama bunu yani yaşamayı en iyi öğrenebileceği yer okul (Ö2)" şeklinde dile getirmiştir.

Eğitimde yaşadıkları sıkıntılar tablosunda katılımcıların tamamına yakını okulda yaşanan en öncelikli ve temel sorunun dil - iletişim sorunu olduğunu ifade etmişlerdi(Tablo 11). Tablodaki verilere göre Suriyeli çocukların yarısından fazlası, velilerin neredeyse tamamı, öğretmen ve koordinatörlerin tamamına yakını ve yöneticilerden 2'si okulun bir diğer katkısının Türkçeyi öğrenmeleri olduğunu dile getirmişlerdir. Bunun farklı bakış açıları kazandırdığını ifade eden öğrencilerden biri fikrini "Dil ögreniyorum ve bu benim biraz daha algımı açıyor haliyle artık dil bildiğim için biraz daha gezme sürecine de girebiliyorum. Yani yeni insanlarla iletişim kurmanın ve yeni dünyalara akabilmenin kapılarını açıyor. Kendi akvaryumumun dışına çıkıyorum anlayacağınız (Ç12)” sözleriyle açıklamıştır. Görüşme yapılan okulların neredeyse tamamında okul yöneticileri dil sorununu ortadan kaldırıp sağlıklı bir iletişim sağlanması için birçok yol denediklerini bunun için kendi bünyelerinde veya farklı kurumlarla iş birliği çerçevesinde okuma yazma kursu açtıklarını, öğretmenlerinin bu konu ile ilgili ekstra bir çaba harcadığını, öğrencilerin dili öğrendikten sonra yaşanan sorunların çoğunun aşılabileceğini ve kendilerini toplumun bir parçası noktasında görebileceklerini ifade etmişlerdir. Bir öğretmen Suriyeli bir çocukla ilk zaman ve sonraki zamanını şu şekilde "Dil bilmediğim için birbirimizin gözüne baktık çoğu zaman. Zamanla dil öğrendikçe ögrenci daha bir sicak ilişki kurup yakınlaşabildiğimizi gördüm. Yani başlangıçta sadece gözlerimin içine bakıp benden beklentisini ifade etmeye çalışan öğrencim sonrasında dili öğrendikçe kendini ifade etme noktasında ve insanlarla ilişki kurma açısından büyük bir gelişme gösterdi (Ö5) sözleriyle dile getirmiştir. Yukarıdaki katkıların yanında öğrencilerin çevreye alışmalarını sağlama, çocukluklarını yaşamalarına olanak sağlama, psikolojik sorunlardan kurtulma veya bu sorunların çocukların üzerindeki etkisini azaltma, aidiyet duygusu kazanma, ülkenin kültürünü tanıma ve kendini güvende hissetme gibi pek çok katkısı olduğu söylenebilir. 


\section{TARTIŞMA, SONUÇ VE ÖNERILER}

Bu bölümde araştırmadan elde edilen veriler tartışılıp Türkiye'de yaşayan eğitim çağındaki Suriyeli çocukların eğitimi sorununun çözümüne dair araştırmacının önerileri sunulacaktır.

\subsection{Tartışma ve Sonuç}

2011 yılında başlayıp o günden bugüne Suriye'de süren iç savaş ve çatışma ortamı milyonlarca insanın yaralanmasına ve ölmesine neden olmuştur. Milyonlarca insanın evleri yıkılmış ve bulundukları bölgeler insanın hayatını idame ettiremeyeceği bir hal almıştır. Milyonlarca insan hayatlarını kurtarmak veya daha iyi bir yaşam kurmak için evlerini, yurtlarını, kaybettikleri akrabalarını ve geçmişlerini ardında bırakarak ülke içinde farklı şehir ve bölgelere veya başka ülkelere göç etmek zorunda kalmışlardır. Ortaya çıkan bu göç sonucu komşu ülkeler arasında durumu daha iyi olan, Suriye ile 911 km'lik sınırı olan ve Avrupa'ya geçişte transit ülke olarak görülen Türkiye, en çok etkilenen ülke olmuştur.

Suriye'den Türkiye'ye ilk toplu nüfus hareketi, 29 Nisan 2011 tarihinde Hatay İli Yayladağ ilçesindeki Cilve Gözü sınır kapısından 252 kişilik bir grupla olmuş ardından bu göç akını günümüze kadar neredeyse aralıksız devam etmiştir. Ekim 2019 itibari ile kayıt altına alınan Suriyeli sığınmacı sayısı 3,6 milyonu aşan Türkiye, Suriye göçü konusunda büyük bir yükün altına girmiştir. Suriye'den gelen göçmenler için ilk başta sınır illerinde 23 geçici barınma merkezi kurulmuş ve Suriyelilerin buralarda barınma ihtiyacı sağlanmaya çalışılmışsa da Göç İdaresi Genel Müdürlüğ̈̈'nün 2019 verilerine göre bu barınma merkezlerinde Türkiye'de bulunan Suriyelilerin \%2'den daha azı yaşamını devam ettirmektedir. \%98'den fazlası Türkiye'nin neredeyse bütün illerine dağılmış bir biçimde hayatlarını devam ettirmeye çalışmaktadırlar. Suriye'deki iç savaş, karmaşa ve çatışmaların henüz bitmemesi, ne zaman biteceğinin de kestirilememesi ve göç edenlerin Türkiye'de uzun yıllar kalacağı fikri sorumluları bu noktada önlemler almaya itmiştir. Bunun yanında, Suriyelilerin neredeyse yarısına yakınının 0-18 yaş aralığında yer alması bu çocukların eğitimleri konusunda politikalar ve projeler geliştirilmesi yönünde sorumluları çözüm üretmeye sevk etmiştir. Türkiye bu konuda bazı çalışmalar gerçekleştirmişse de yapılan çalışmalar Suriyeli mültecilerin yaşadıkları problemleri tamamen çözme noktasında yeterli olmamıştır. Özelikle geçici barınma merkezleri dışında yaşayan Suriyelilerin problemlerine yönelik çalışmalar yetersiz kalmıştır.

Araştırma sonucu elde edilen verilere göre Kızıltepe'de yerleşen Suriyelilerin Türkiye'yi tercih etme nedenlerinin başında, Türkiye'nin komşularına oranla daha güvenli bir ülke olarak görülmesi gelmektedir. Türkiye'deki yerler arasında Mardin'in Kızıltepe ilçesini tercih etmelerindeki temel sebepler ise akrabalık ilişkileri ve iletişim kurabilecekleri bir dilin varlığıdır. Katılımcıların neredeyse tamamına yakını buraya gelmelerinde veya kalmalarında akrabalık ilişkilerinden bahsetmiştir. Bu durum bize Kızıltepe'ye yerleşen Suriyelilerin sosyal ağlarının çok güçlü olduğunu ve bu ağların göç etme ve yer seçmede çok etkili olduğunu göstermektedir.

Araştırma sonucu elde edilen verilere göre Kızıltepe'de yaşayan Suriyeli sığınmacıların en temel sorunu Suriyeli olmak üzerinden karşılaştıkları önyargılar ve kurulan iletişim dilidir. Durumları, bakış açıları veya fikirleri ne olursa olsun bu insanlar neredeyse gittikleri her yerde Suriye'den geldikleri için üzerlerine yapışmış bu etiketle dışlanma ile karşı karşıya kalıyor veya onlarla bu etiket üzerinden iletişim kuruluyor. Farklı bir ilişski kurma şansı bırakmayan bu bakış açısı Suriyelilerin kendileri açısından gördükleri en önemli sorun olarak karşımıza çıkmaktadır. Özellikle çocukların ve gençlerin kendileri ile iletişim kurulduğunda hitap olarak isimleri yerine sürekli "Suri” diye çağrılmasından büyük üzüntü yaşadıklarını ve bu durumun çocukların ve gençlerin hayata karşı olumlu bir bakış açısı geliştirmelerinin önündeki en büyük engel olduğunu söyleyebiliriz. Bunun yanında bir diğer temel sorun da iletişim sorunu olarak karşımıza çıkmaktadır. Gençlerin ve çocukların yaşadıkları bu sorundan kaynaklı olarak yaşamlarının zorlaştığını, kendilerini ifade etmekte sorun yaşadıklarını ve bu durumun kendilerini yalnızlık ve yabancılık duygusu içine ittiğini ifade edebiliriz. Çünkü bu durum çocukların ve gençlerin kendilerini toplum içinde var etmesini ve toplumda bir yer edinmesine engel olmaktadır. 
$\mathrm{Bu}$ durum çocukların kendi geçmişlerinden uzaklaşmasına ve uyruklarıyla yaşanan sorun arasında bağ kurmalarına sebep olmaktadır.

Birçok araştırmada (Kaştan, 2015, Kultas, 2017, Apak, 2014) en temel sorun olarak barınma ve işsizlik sorunu olarak karşımıza çıkarken, Kızıltepe'de yaşayan Suriyelilerin en temel sorunu çalışmadaki bulgulara göre, Suriyeli olmalarından kaynaklı ortaya çıkan etiket, bunun doğurduğu önyargılar ve bunun neticesi olarak geliştirilen iletişim dilidir. İşsizlik ve barınma sorunu; iletişim dili ve buna bağlı olarak ortaya çıkan dişlanma, yalnızlık ve yabancılık sorunlarından sonra gelmektedir. Barınma ve işsizlik sorunlarının Kızıltepe'de öncelikli sorun olmamasının nedeni iki nokta ile açıklanabilir. Birinci nokta, Suriye'den Türkiye'ye göç edip Kızıltepe'ye gelen Suriyelilerin pek çoğunun ya yerel halktan akrabalarının olması ya da onlardan önce buraya gelen akrabalarının olması, geldiklerinde bu konuda çok fazla sıkıntı yaşamamalarını sağladığı düşünülebilir. Başka bir şekilde ifade etmek gerekirse, Kızıltepe'ye yerleşen Suriyelilerin mevcut veya buraya geldikten sonra kurdukları sosyal ağlar sayesinde bu sorunlarını aştıkları ifade edilebilir. Çalışma kapsamında Kızıltepe'ye yerleşen Suriyelilerin kurdukları sosyal ağların çok güçlü olduğu ortaya çıkmıştır. Bu durum araştırmaya katılan STÖ temsilcileri ve okul yöneticileri tarafından benzer şekilde yorumlanmıştır. İkinci nokta ise, Kızıltepe'ye yerleşen Suriyelilerin uzun yıllardır burada kaldıkları için bu sorunu bir şekilde çözüp atlatmışlardır ve bu sorun öncelikli sorunları arasından çıkmıştır. Tabi ortaya çıkan bu durum barınma ve ișsizlik sorununun hiç yaşanmadığı anlamına gelmemektedir. Araştırmadaki bulgulara göre barınma sorunları Kızıltepe'de yaşayan Suriyelilerin başka bir sorunudur. Yaşanan barınma sorunlarının temeli kötü durumda olan evlerde kalmak ve bu evlerin kendilerine çok pahalıya kiralanması olarak karşımıza çıkmaktadır. İşsizlik sorununda da benzer bir durumun yaşandığını görmekteyiz. Yerli olan insanlardan daha fazla çalıştırıldıkları halde sosyal güvencesiz ve yerli olan işçilerden çok daha ucuza çalıştırıldıkları görülmüştür. Ayrıca özellikle çalıştıkları sektörlerden biri olan tarıma elverişli toprakların bulunduğu yerlerde açılan kuyu başlarında çalışmak çocuklarının eğitime ulaşmasının önündeki en temel sıkıntı olarak karşımızda durmaktadır.

Suriyelilerin geleceğe yönelik planlarında Suriye'ye geri dönme isteklerinin ve ümitlerinin günden güne azaldığını görmekteyiz. Çalışma kapsamında Kızıltepe'de yaşayan Suriyelilerin çok azı geri dönmeyi planladığını ifade etmiştir. Bu kapsamda Amman ve Altındiş yaptıkları çalışmada, Suriye'deki çatışma ortamının devam etmesi, gelenlerin Türkiye'ye alışması, bir düzen kurması ve topluma uyum sağlaması neticesinde Türkiye'ye gelen sığınmacıların ülkelerine geri dönme eğilimini azalttığını ve savaş bitse bile büyük bir kısmının Türkiye'de kalmaya devam edeceğinin ön görüldüğünü ifade etmesi çalışmamızda çıkan bulguları desteklemektedir (2019, s. 17).

Araştırma sonucu ortaya çıkan ve yukarıda bahsettiğimiz sorunların dışındaki bir diğer önemli sorun ise araştırmamızın da temelini oluşturan okul çağındaki Suriyeli çocukların eğitimi sorunudur. Bu sorun, Türkiye genelinde olduğu gibi, Türkiye'nin tüm illerinde yaşayan Suriyelilerin çözülmesi gereken en temel sorunların başında gelmektedir. Savaşın çıktığı ilk zamanlar bu sürecin çok uzun sürmeyeceği ve Türkiye'ye göç eden Suriyelilerin kısa bir zaman içinde ülkelerine dönecekleri hesapları üzerinden kısa vadeli politikalar sadece kampta kalan çocuklara yönelik hazırlanmıştır. Ancak savaşın kısa zaman içinde bitmeyeceği anlașılınca Suriyeli çocukların eğitimi üzerine politikalar üretilmeye başlanmıştır. Öncelikle barınma merkezlerinde daha sonrasında ise farklı farklı illerde açılan Geçici Eğitim Merkezlerinde, Suriyeli çocuklara kendi dil ve müfredatlarına uygun eğitim verilmeye başlanmıştır. Ancak bu merkezlerde eğitimine devam eden Suriyeli öğrenciler, Türkiye'de bulunan okul çağındaki Suriyeli çocukların yaklaşık \%30'unu teşkil etmektedir. Göç İdaresi Genel Müdürlüğünün 2016 verilerine göre bu oran \%13 iken 2017 yılında yaklaşık \%30 olmuştur. Daha sonraki süreçte ise Suriyeli öğrenciler Türk Eğitim Sistemine dahil edilerek Geçici Eğitim Merkezleri kademeli olarak kapatılmıştır. 2018-2019 eğitim öğretim yılında kayıtlı Suriyeli sayısı \%61,25'e ulaşmıştır. Yapılan tüm çalışmalara rağmen okula erişemeyen eğitim çağındaki Suriyelilerin sayısı \%40'a yakındır. Mardin İl Milli Eğitim Müdürlüğü'nden alınan verilere göre Kızıltepe'de eğitim çağında yaklaşık 8800 Suriyeli çocuk olmasına rağmen bunlardan sadece 3626 tanesi yani \%41'e yakını okula devam edebilmektedir. Bu çocukların \%60'a yakını eğitim ve öğretim faaliyetlerinden yararlanamamaktadir.

Araştırmadan elde edilen verilerden yola çıkarak Kızıltepe'de eğitimlerine devam eden Suriyeli öğrencilerin yaşadıkları en temel sorun dil ve iletişim sorunudur. Akalın 2016 yılında göçmen çocuklarının uyumu üzerine gerçekleştirdiği araştırmasında göçten sonra dil ve uyum sorunun en önemli problem olduğu sonucuna ulaşması araştırmamızda çıkan bulguları desteklemektedir. Eğitim 
çağındaki Suriyeli öğrenciler hazırbulunuşluk durumları belirlenmeden ve dil problemi halledilmeden Türkiye eğitim sistemine dahil edilmişlerdir. Süreç içerisinde Halk eğitim merkezlerinde veya bazı okullarda oryantasyon çalışmaları yapılmış, okuma-yazma veya dil kursları açılarak bu öğrenciler desteklenmeye çalışılmışsa da elde edilen veriler bu çalışmaların yeterli olmadığını göstermektedir. Bazı Suriyeli öğrenciler dil açısından belli bir seviyeye gelip eğitimden belli bir oranda verim aldıysa da genel olarak bu öğrencilerde dil sorunun yaşandığı ve bu sorundan kaynaklı olarak eğitim ve öğretim faaliyetlerinden yeterince faydalanamadığı ortaya çıkmıştır.

Dil problemi Suriyeli öğrencilerin okul tercihlerini de etkilemektedir. Suriyeli öğrencilerin genellikle imam hatip liselerini tercih ettikleri bu tercihlerinin de temel sebebinin bu liselerde Arapça dil eğitimi verilmesi ve derslerin bir kısmının Arapça olmasından kaynaklı olduğu görülmüştür. Özer, Komşuoğlu ve Ateşok (2016, s. 94)'da yaptıkları çalışmada, Dil konusunun okul tercihine yansıdığını, ailelerin iletişim kurabilecekleri ve kayıt sürecinde yardım alabilecekleri Arapça bilen yöneticilerin olduğu okulları daha fazla tercih ettiklerinin görüldüğünü ifade etmeleri bu durumu destekler niteliktedir. Bu durum öğrenci açısından dil probleminin çok büyük olduğunu ve bir an önce çözülmesi gerektiğini bir kez daha karşımıza çıkarmaktadır. Öğrenci yaşadığı bir sıkıntı sebebiyle var olan seçeneklere çok fazla bakmadan sadece bu problemini bir nebze de olsa çözecek okula yöneliyor. Bunun yanında bu okulların tercih edilmesinde maddi sorun ve okulun eve yakın olması da bir etken olarak karşımıza çıkmaktadır.

Araştırmada elde edilen bulgulara göre, eğitime dahil olan Suriyeli öğrencilerin yabancılık, yalnızlık, dışlanma ve derslerde yeterli verimi almamalarından dolayı başarısızlık gibi sorunlar yaşadıkları sonucuna varılırken, okulun bu öğrencilere arkadaşlık, sosyal ortam, yeni bir kültür tanıma psikolojik sorunlardan uzaklaşma ve kurtulma gibi birçok alanda katkı sağladığı sonucuna da varılmıştır. Bu sorunların giderilmesi ve okulların katkısının artırılması için yöneticiler, öğretmenler ve koordinatörler tarafından öğrencilere maddi yardımda bulunma, Türkçe dil kurslarının verilmesi, eğitim dilinin Arapça olması ve öğretmenlerin daha ilgili olması gibi istekler doğrultusunda çeşitli tedbirler alınmaya çalışılmış ancak bu tedbirler okulun şartları ve imkanlarının el vermemesi sebebiyle kısmen faydalı olmuştur.

Sonuç olarak, Kızıltepe'de yaşayan öğrencilerin eğitim sorununun çözülmesi için onların eğitimlerinin önündeki tüm engeller kaldırılmalıdır. Maddi destek, okula uyumlarını artıracak faaliyetler ve dil eğitimi öncelikli çözülmesi gereken sorunlardır. Bu konuda valilik, belediyeler, milli eğitim müdürlükleri ve sivil toplum örgütleri koordineli bir şekilde çalışarak sistemli bir program dahilinde hareket edilmesi gerekmektedir. Bu noktada araştırma sonucunda ulaşılan aşağıdaki önerilerinde dikkate alınarak bu çocukların bir an önce eğitim sorunlarının çözülmesi, eğitime erişememişlerin ise eğitim sistemine dahil edilmesi gerekmektedir.

Bu çalışma kapsamında, Türkiye'de bulunan Suriyeli mülteci çocukların eğitim sistemi içerisindeki deneyimleri kapsamında yaşadıkları sıkıntılar tespit edilerek sunulan eğitim hizmetlerine yönelik iyileştirici önerilerde bulunulmuştur.

\section{2. Öneriler}

Çalışma kapsamında ilk olarak göze çarpan durum Suriyeli mülteci çocuklara yönelik olarak yapılan çalışmaların yeterli düzeyde olmaması veya sunulan imkanlardan yeterli düzeyde yararlanılamaması olarak karşımıza çıkmaktadır. Bu durumun çeşitli sebepleri mevcuttur. Özellikle koordinasyon eksikliği ve eğitime erişim sıkıntısı bunların başını çekmektedir. Bu kapsamda öncelikle il milli eğitim müdürlüklerinin altında Suriyelilerin eğitim ve öğretim durumlarıyla ilgilenen bir birim oluşturulması gerekmektedir. Bu birim öğrencilerin devam ve devamsızlıklarının kontrolünün yapılması, kayıtlı olup okula devam etmeyen öğrencilerin okula kazandırılması için yapılan çalışmaların takibi, Kızıltepe'de yaşayan Suriyeli öğrencilerin demografik bilgilerinin toplanarak, geliştirilecek eğitim politikalarının bu çerçevede hazırlanması gibi pek çok alanda çalışmalar yürütebilecek kapasitede olmalıdır.

Suriyeli öğrencilerin eğitime erişememe veya devam sağlayamamasının temel nedenlerinden biri de maddi açıdan yaşadıkları sıkıntılardır. Bu temelde öğrencilerin eğitimlerinin önünde engel teşkil eden barınma ve beslenme gibi temel ihtiyaçların yanında okula erişim için kullanılan servis ücretleri sorunun da tespit edilerek giderilmesi önemli bir durumdur. Ayrıca eğitimde gerekli olan materyal, okul araç-gereçleri ve okul üniforması gibi temel ihtiyaçların devlet tarafından ücretsiz karşılanması eğitime erişimi kolaylaştıracak faaliyetlerdendir. 
Kızıltepe'de yaşayan Suriyelilerin okula kayıt oranlarını incelediğimizde okul öncesi ve lise düzeyinde öğrencilerin kayıt oranlarının ve okula devam oranlarının çok az olduğu görülmektedir. Bu öğrencilerin kayıt oranlarının artırılması ve okula devamlılıklarının sağlanması için gerekli çalışmalar yürütülmelidir. Özellikle okul öncesi dönemde eğitime erişimi artırmak Kızıltepe'deki Suriyeli öğrencilerin sorunlarının başında gelen dil problemini de büyük oranda çözecektir. Bu durumlarla ilgili gerekli çalışmalar yapılmalı özellikle okul öncesi eğitimi ihtiyaç duyulması halinde zorunlu hale getirilmelidir.

Mülteci çocukların özellikle kendilerini ifade etmeye ihtiyaç duymaktadırlar. Yaşadıkları durumları ve deneyimleri rahat bir şekilde anlatabilecekleri bir ortama sahip olurlarsa sorunlar birikmeden anlık müdahalelerle çözülebilecektir. $\mathrm{Bu}$ kapsamda kız ve erkek çocukların kendilerini rahat ifade edebilmeleri için aynı okulda kadın ve erkek rehber öğretmenlerinin birlikte görevlendirilmesine dikkat edilmelidir. Her okulda en az bir dil bilimci ve bir sosyal çalışmacı görevlendirilmelidir. Bununla birlikte okulda bulunan eğitici, koordinatör ve öğretmenlerin yanı sıra göre alan diğer tüm personele de Suriyeli çocukların zorlu yaşam koşulları, hakları, travma, göç ve savaş psikolojisi gibi alanlarda hizmet içi eğitimler verilmeli ve bunun sürekliliği sağlanmalı, mümkünse çok dilli öğretmenler yetiştirilmelidir.

Suriyeliler çocuklar eğitim sistemine dahil olma sürecinde özellikle okula kayıt yapma veya kendi seviyesine uygun sınıflarda okuma noktasında sıkıntılar yaşamaktadır. Suriyelilerin eğitime dahil olmaları için gerekli olan ve ancak Suriye'den getirebilecekleri belgelerin istenmesi yerine seviyelerini belirleyebilecek bir sınav sistemi geliştirilmesi birçok öğrencinin eğitime erişiminin önünü açacaktır. Aynı zamanda öğrenciler eğitim öğretime dahil edilirken hazırbulunuşluk düzeyleri belirlenmeli ve öğrenciler hazırbulunuşluk düzeylerinin gerektirdiği sınıflara yerleştirilmelidir. Bu durum öğrencilerin kendi seviyelerinde eğitim almasını ve bu sayede eğitim sürecinde daha az sıkıntı yaşamalarını sağlayacaktır.

Çalışma kapsamında Suriyelilere yönelik ön yargının belirgin olarak sorunlara yol açtığını görmüştür. Bu noktada özellikle toplumsal uyumun sağlanması için sadece çocuklar arasında değil aileler arasında da kaynaşmayı sağlayabilecek ve önyargıların kırılmasını sağlayabilecek çalışmalar önem kazanmaktadır. $\mathrm{Bu}$ kapsamda iki toplum arasında tanınırlığı ve teması artıracak etkinlikler ve programlar planlanmalıdır. Okullarda görev alan Suriyeli gönüllü eğiticilerin yardımıyla özellikle Suriyeli ailelerle görüşmeler sağlanarak ailelerin okul ile sıcak ilişkiler kurması sağlanmalıdır.

Okul süreci içerisinde çocukların olumlu kişilik geliştirmesinde ve sorunlarından kurtulmalarına yardımcı olan, çocukları sosyal olarak geliştirmede etkili teknoloji ve tasarım, beden eğitimi, görsel sanatlar ve müzik gibi derslerde yapılan etkinliklere Suriyelilerin dahil edilmesine dikkat edilmeli ve seçmeli derslerde de bu tarz derslere ağırlık verilmelidir. Ayrıca çocuklar arasında empatiyi geliştirecek etkinlik ve uygulamaların ders müfredatına eklenmesi önemlidir.

Anadili Türkçe olmayan çocuklara yönelik olarak çocuğun seviyesine uygun olarak eğitim-öğretim y1lı başlamadan veya eğitim-öğretim yılı içerisinde zorunlu Türkçe ek dil dersleri verilmedir. Telafi ve destekleme kursları eğitim alan tüm çocukları kapsayacak şekilde oluşturulmalı ve sürekli ve düzenli hale getirilmelidir. Bunun yanında çocuğun anadiline de önem verilip, anadilini ve geldiği kültürü öğrenebileceği dersler okutulmalıdır. Bu kapsamda hem Türkçe hem de anadil başarısı uygun yöntemlerle takip edilmelidir. Bunun yanında öğretim programı ve eğitim materyalleri çok kültürlülügü, farklılıklara saygı göstermeyi, toplumsal cinsiyet eşitliğini, düşünce özgürlüğü ve eşitlik fikirlerini destekleyecek şekilde oluşturulmalıdır.

Türkçe öğretimi sadece okuldaki öğrencilerle sınırlı kalmamalı, zorunlu eğitim dışına çıkmış veya toplumdaki diğer bireylere yönelik olarak da çalışmalar yapılmalıdır. Bu kapsamda okul-halk eğitim merkezleri ve okul-yerel yönetimler gibi sürekli ve düzenli işbirliği çalışmaları ile eğitim verilmesi sağlanmalıdır. Eğitimler ihtiyaca göre akşam saatlerinde de düzenlenebilmelidir.

Okullarda Suriyeli çocukların durumlarını takip edip sorunları ile ilgilenen Suriyeli gönüllü eğiticilerin sayılarının artırılıp maddi olarak kazanlarının iyileştirilmesi sürecin daha verimli olmasına katkı sağlayacaktır. Bu eğiticiler hem öğrencilerin sorunlarının çözülmesinde etkin bir rol oynamakta hem de aile okul işbirliğinde aktif bir şekilde rol oynamaktadırlar.

Son olarak çocukların eğitiminde sivil toplum örgütleriyle koordineli çalışılmalı ve sivil toplum örgütleri tarafından hazırlanan raporlar dikkate alınarak şeffaf bir süreç izlenmelidir. 
AFAD (Afet ve Acil Durum Yönetimi Başkanlığı) (2016). Suriye raporları. T.C. Başbakanlık Afet ve Acil Durum Yönetimi Başkanlığı. https://www.afad.gov.tr/tr/25296/Suriye-Raporlari. Erişim Tarihi: 26.07.2019.

Akalın, A. T. (2016). Türkiye'ye gelen Suriyeli göçmen çocukların eğitim sorunları. İstanbul Aydın Üniversitesi Sosyal Bilimler Enstitüsü. Yüksek lisans tezi.

Akan, Y. ve Arslan, İ. (2008). Göç ekonomisi: Türkiye üzerine bir uygulama. Ankara: Ekin Yayınevi, $21-25$.

Amman. M. T. ve Altındiş, E. (2019). İstanbul' da Yaşayan Geçici Koruma Statüsündeki Suriyelilerin Türk Vatandaşlığına İlişkin Görüşleri. Sosyal ve Kültürel Araştırmalar Dergisi (5). 9, 1-20.

Apak, H. (2014). Suriyeli göçmenlerin uyumu ve gelecek beklentileri. Mardin Artuklu Üniversitesi Sosyal Bilimler Enstitüsü. Yüksek lisans tezi.

Boston, H. (2018). Geçici Koruma Statüsündeki Suriyelilerin Uyum, Vatandaşlık ve İskan Sorunu, Göç araştırmaları Dergisi. 4(2), 33-88.

Beter, Ö. (2006). Sinırlar ötesi umutlar. Ankara: Sabev Yayınları, 5-6

Castles, S. ve Miller, M. (2008). Göçler çă̆ı. İstanbul: İstanbul Bilgi Üniversitesi Yayınları, 39.

Dinçer, Ö. (2012). Oyunun kuralı değişmemeli. Dünya bülteni. http://www.dunyabulteni.net/servisler/haberYazdir/221066/haber. Erişim Tarihi: 20.06.2019.

Ekici, S. ve Tuncel G. (2015). Göç ve İnsan, Birey ve Toplum, 5(9), 9-22.

Fichter, J. (2006). Sosyoloji nedir. (Çev. Nilgün Çelebi). Ankara: Anı yayıncılık.

GİGM (Göç İdaresi Genel Müdürlüğü) (2019). Göç istatistikleri. https://www.goc.gov.tr/icerik6/gecicikoruma_363_378_4713_icerik. Erişim Tarihi: 10.10.2019.

Güllüpınar, F. (2019). “Göç ve Türkiye'de göçün sosyolojiz analizi,” Göç ve Sağlık (Ed. Y.

Pekşen), Ankara: Sağlık Bakanlığı Yayınları, 18-28.

International Organization for Migration-IOM (2018). World migration report, Geneva: The UN Migration Agency Press.

Kultas, E. (2017). Türkiye'de Bulunan Eğitim Çağındaki Suriyeli Mültecilerin Eğitim Sorunu: Van ili Örneği. Yüzüncü Yıl Üniversitesi Eğitim Bilimleri Enstitüsü. Yüksek Lisans Tezi.

Kutlu, Z. (2015), "Bekleme Odasından Oturma Odasına: Suriyeli Mültecilere Yönelik Çalışmalar Yürüten Sivil Toplum Kuruluşlarına Dair Kısa Bir Değerlendirme”, Anadolu Kültür \& Açık Toplum Vakfi, Ocak-Nisan.

Orhan, O. ve S. Şenyücel (2015). Suriyeli Siğınmacıların Türkiye’ye Etkileri, İstanbul: ORSAM \& TESEV Raporu, No $195 . \quad$ https://www.tesev.org.tr/wpcontent/uploads/rapor_Suriyeli_Siginmacilarin_Turkiyeye_Etkileri.pdf.

Özer, Y. Y., Komsuoğlu, A. ve Ateşok, Z. Ö. (2016). Türkiye'deki Suriyeli Çocukların Eğitimi: Sorunlar ve Çözüm Önerileri. The Journal of Academic Social Science, Y11.4, Sayı.37, 76-110. 
Palabıyık, A. ve Koç, Y. (2011). "Zorunlu Göç ve Fakirliğin Diğer Adı: Mülteciliğin Dünyada ve Türkiye'deki Gelişimi (2004-2007)" International Conference on Eurasian Economies, SESSION 5B: Büyüme ve Gelişme I, 325-334.

Seydi, Ali R. (2014). Türkiye'nin Suriyeli sığınmacıların eğitim sorununun çözümüne yönelik izlediği politikalar. SDÜ Fen Edebiyat Fakültesi Sosyal Bilimler Dergisi. 31, 267-305.

Sirkeci, İ. (2017). "Bir Güvensizlik Ülkesi Olarak Türkiye'nin Mültecileri: Suriyeliler ve Türk Mülteciler”, Göç Dergisi, 4 (1), 21-40.

Taşcı, F. (2009). Bir Sosyal Politika Sorunu Olarak Göç. Kamu-İş. 10(4), 177-204.

UNHCR (The UN Refugee Agency) (2015). Türkiye'deki Suriyeli Mülteciler: Stk Sorulan Sorular. http://www.unhcr.org/. Erişim Tarihi: 23.12.2018.

Yalçın, C. (2004). Göç sosyolojisi. Ankara: Anı Yayıncılık.

Yılmaz, E. ve Güllüpınar, F. (2019). “Cihanbeyli ve Kulu'dan Avrupa'ya göçlerin sosyolojik ve tarihsel analizi: Kuşaklar üzerinden bir değerlendirme”, (Ed. Alaattin Aköz vd.) Geçmişten günümüze göç: Konya kitabı. Konya: Konya Ticaret Odası Yayınları, 63-89. 